NBER WORKING PAPER SERIES

\author{
BIOFUELS, BINDING CONSTRAINTS AND AGRICULTURAL COMMODITY \\ PRICE VOLATILITY \\ Philip Abbott \\ Working Paper 18873 \\ http://www.nber.org/papers/w18873
}

\author{
NATIONAL BUREAU OF ECONOMIC RESEARCH \\ 1050 Massachusetts Avenue \\ Cambridge, MA 02138 \\ March 2013
}

The author would like to thank Wally Tyner, Chris Hurt, Tom Hertel, Brian Wright, an anonymous referee and participants at the NBER conference on "Economics of Food Price Volatility" for sharing their insights on the issues discussed in this paper. The views expressed herein are those of the author and do not necessarily reflect the views of the National Bureau of Economic Research.

NBER working papers are circulated for discussion and comment purposes. They have not been peerreviewed or been subject to the review by the NBER Board of Directors that accompanies official NBER publications.

(C) 2013 by Philip Abbott. All rights reserved. Short sections of text, not to exceed two paragraphs, may be quoted without explicit permission provided that full credit, including $(\mathbb{C}$ notice, is given to the source. 
Biofuels, Binding Constraints and Agricultural Commodity Price Volatility

Philip Abbott

NBER Working Paper No. 18873

March 2013

JEL No. Q02,Q16

\begin{abstract}
$\underline{\text { ABSTRACT }}$
The share of U.S. corn production used to produce ethanol increased from $12.4 \%$ in the 2004/05 crop year to over $38.5 \%$ in the $2010 / 11$ crop year, and remained at that high level in $2011 / 12$. Even after accounting for return of by-products to the feed market, this is a large and persistent new demand for corn that surely has changed price dynamics. Nevertheless, the role of biofuels in determining recent high corn and other agricultural commodity prices, as well as their volatility, remains controversial.

Policy measures to encourage biofuels production, including the Renewable Fuels Standard (RFS) mandates, subsidies to ethanol blenders, regulations on gasoline chemistry and import tariffs, helped to create this new, persistent demand for corn and contributed to incentives to create the capacity to produce ethanol and to use corn for fuel rather than food. Various aspects of implementing that policy and the economics of ethanol plant operation suggest very inelastic industrial demand for corn, contributing to both higher prices and greater price volatility. But turbulence in recent economic events have caused the mechanisms through which biofuels demands influence corn and other agricultural commodity prices to vary over time in ways that are observable in data. Price volatility and "subsidy incidence" also depend on which regime is in place. Simple theory along with data on supply, use and pricing are used to identify when each regime matters as policy influenced constraints bound to varying degrees. Capacity constraints appear to have dominated in the short run, allowing rents to absorb differences in variations of corn prices versus energy prices. Apparent price volatility seems due to mechanism switching and to changing trends more so than to random short run shocks under inelastic demand.
\end{abstract}

Philip Abbott

Department of Agricultural Economics

Purdue University

Krannert Bldg, Rm 576

403 W State Street

West Lafayette, IN 47907-2056

Phone:(1) 765-494-4274

abbottpc@purdue.edu 


\section{Biofuels, Binding Constraints and Agricultural Commodity Price Volatility}

\section{Introduction}

The share of U.S. corn production used to produce ethanol increased from $12.4 \%$ in the $2004 / 05$ crop year to over $38.5 \%$ in the 2010/11 crop year, and remained at that high level in 2011/2012 (ERS, 2012). Even after accounting for return of by-products to the feed market ${ }^{1}$, this is a large and persistent new demand for corn that surely has changed price dynamics (Wright, 2011; Abbott, Hurt and Tyner, 2008 and 2011). Moreover, policy measures to encourage biofuels production, including the Renewable Fuels Standard (RFS) mandates, subsidies to ethanol, regulations on gasoline chemistry and import tariffs, have contributed to incentives to create the capacity to produce ethanol and to use corn for fuel rather than food (Tyner, 2008 and 2011).

The role of biofuels in determining high agricultural commodity prices in both 2007-08 and 2011 (as well as in drought affected 2012) remains controversial, nevertheless (National Academy of Sciences, 2011). Some have argued since the 2007-08 food crisis that increased biofuels demand has been a key factor for both the level and volatility of commodity prices (Mitchell, 2008; Collins, 2008; Abbott, Hurt and Tyner, 2008 and 2011). Others assert that biofuels shocks should mostly affect corn, and that common factors across commodities are more important in explaining price increases (Gilbert, 2010; Baffes and Haniotis, 2010). The link between energy and corn prices, according to their logic, is the result of speculation and/or macroeconomic factors, not biofuels. Others have argued that these common factors are less important (Irwin and Sanders, 2011; Ai, Charath and Song, 2006). A Texas A\&M study in 2008 (Agricultural Food and Policy Center, 2008) also argued for a link from input costs, especially fertilizer and fuel, to agricultural production, but a history of short run losses by farmers when commodity prices have been low relative to input prices argues this factor may be influential only in the longer run. Time series econometric investigations have been inconclusive (Heady and Fan, 2010), with some identifying structural change just before the 2007-08 food crisis (Enders and Holt, 2012; Harri, Nalley and Hudson, 2009), but offering little economic insight into the changes found. McPhail (2011) has even argued that causality runs from ethanol demand to crude oil prices, not in the other direction. Calibrated simulation models have also struggled to reproduce plausible effects from biofuels on agricultural prices (Babcock and Fabiosa, 2011; Hertel and Beckman, 2012). Many studies have as a result been vague in assigning the relative significance of factors behind high agricultural commodity prices (e.g. Trostle, 2009).

The notion that commodity prices had become not only higher but also more volatile emerged early in the debate on the energy-biofuels-agricultural commodity price relationships (Delgado, 2009). Numerous studies have investigated commodity price variability, using both time series econometrics (Balcombe, 2009; Cha and Bae, 2011; Gilbert, 2010) and calibrated simulations (e.g., Hertel and Beckman, 2011; Gohin and Treguer, 2010; Diffenbaugh, Hertel, Sherer and 
Verma, 2012). Even the notion that agricultural commodity prices are now more volatile has faced some controversy, however. Whether volatility is measured by variances, coefficients of variation, or deviations from a short run trend matters, as does the interdependence of factors influencing conditional volatility (Balcombe, 2009). The role of policy incentives and constraints has emerged as a key factor in this debate, especially EPA regulations.

It has been argued that this new demand for corn is highly inelastic, contributing to greater corn price volatility, if it is the result of meeting a policy-set minimum - the RFS mandate (Tyner, Taheripour and Perkis, 2010; deGorter and Just, 2009; Hertel, Tyner and Birur, 2010) . Others have noted that a "blend wall" - a limitation on the percentage of ethanol that may be used with gasoline regulated by the EPA - may establish maximum ethanol use, and that this maximum was by 2011 not far from the minimum set by the RFS for corn-based ethanol (Tyner and Viteri, 2010). Recent models have at times used a combination of mandated ethanol use with blend wall limitations to capture effects on agricultural commodity prices (McPhail and Babcock, 2012; Tyner, 2010). But in 2011 exports of ethanol increased dramatically (Wisner, 2012; Collins, 2011), suggesting capacity constraints rather than the RFS mandate or "blend wall" may determine ethanol production and so industrial demand for corn, at least in the short run. Capacity constraints have been important to varying degrees throughout the evolution of corn/ethanol demand, as capacity has been increased to stay ahead of the RFS mandate and in response to market and policy determined incentives.

During this period of increased use of corn for ethanol, several regimes can be identified based on which constraint on ethanol demand is binding. In 2005-06, low corn prices and high crude oil prices, hence high gasoline prices, likely led to rents to binding ethanol capacity constraints as incentives to increase that capacity. Only in late 2008 and early 2009 has there been a significant, non-zero price for ethanol RINS (the instrument to insure the RFS mandate is met and to allow sale of "quota rights" under the mandate), indicating that this minimum seldom binds (Thompson, Meyer and Westhoff, 2010; OPIS, 2012; Paulson, 2012). In 2011 the blend wall may have limited domestic demand, but exports brought ethanol production near plant capacity. In 2012, subsidies ended, exports declined, production has fell below capacity, and the blend wall became more limiting. In early 2008 it may have been the case that high oil prices drove demands for ethanol and corn that were above mandates but below capacity or blending constraints, so variations in the crude oil price were transmitted to corn prices. As we shall see below, when capacity constraints bind, the direct link between corn and energy prices through biofuels is weaker.

Which constraint is binding, if any, determines relationships between corn, ethanol, gasoline and crude oil prices. It also determines whether industrial demand for corn is essentially perfectly inelastic or is adjusting in response to relative corn and/or energy prices. When demand is more inelastic, hence when a constraint is binding, corn prices will be more volatile, and that will likely spill over onto other crops. It is likely that there have been several different regimes 
between 2005 and 2011, based on variations in which constraint binds, explaining structural shifts observed in econometric estimation of price relationships.

Evidence on what is determining ethanol and corn pricing and demand should be seen in both supply-utilization balances relative to capacity, the mandate and the "blend wall"; and in margins between relevant prices. A careful examination of detailed short term data on corn, ethanol and gasoline market performance is one approach that has been noticeably absent in the debate on biofuels and volatility. Therefore, simple theory will be developed here that incorporates these constraints on ethanol demand, and predictions of that theory under alternative regimes will be compared to actual price and quantity data. Empirical application of that theory may be used to compare predicted versus actual price volatility that varies over critical periods, and will also show how the benefits of subsidies and mandates are shared between farmers, ethanol producers, blenders, and gasoline refiners as the regime changes. The underlying incentives for exports either mandates elsewhere or profitable substitution for gasoline - will also be explored to gauge whether and how they will influence future increases in ethanol production capacity.

In summary, energy policy favoring biofuels has helped to create a new, large and persistent demand for corn. Various aspects of implementing that policy suggest very inelastic industrial demand for corn, contributing to both higher prices and greater price volatility. But turbulence in recent economic events has caused the mechanisms through which biofuels demands influence corn and other agricultural commodity prices to vary over time in ways that should be observable in data. Price volatility and "subsidy incidence" depend on which regime is in place. Simple theory along with data on supply, use and pricing can be used to identify when and to what extent each regime matters.

In the next section, trends and apparent volatility in the relationship between corn and crude oil prices are presented to justify the origins of this debate on volatility and to gauge the relative importance and extent of short run versus long run volatility. Details on the policy determined constraints that impact ethanol and corn are then briefly elaborated and a timeline is developed showing when each constraint is most likely to have mattered. Theory related to decisions by gasoline blenders and ethanol producers under these constraints is then developed, followed by the links these create from ethanol to the U.S. corn market. Supply and use balances in the corn market are considered in light of this theory. Special attention is then given to ethanol trade and its implications for market outcomes and modeling. Both quantity and price outcomes are then investigated using monthly data for crude oil, gasoline, corn and ethanol as well as the timeline of policy set constraints and external economic shocks. Short and long run volatility is also examined across these "watershed" periods. Conclusions emphasize how important biofuels have been in determining agricultural market outcomes, and how binding constraints have shaped the evolution of agricultural commodity prices. 


\section{Apparent Volatility}

Figure 1 presents monthly corn and crude oil prices from 1960 to 2012. Over this longer time horizon these series exhibit imperfectly long periods of relative stability interrupted by shortlived spikes that are sometimes noted in the literature (reviewed in Abbott, 2010). The spikes appear more frequently for corn, and trends appear to last longer for crude oil. While some longer term correlation may be seen between these series, there also appear to be periods when these prices are less well connected. The upward trend of these prices is largely due to inflation, as similar graphs of these series when deflated would exhibit variations around downward trends from the early 1970s onward. The U.S. CPI is also shown on Figure 1 to demonstrate this effect.

[ Figure 1. Corn and Crude Oil Prices, 1960-2012. about here ]

Three questions related to these series are investigated here: How is variability properly measured? Does it differ for short run versus long run perspectives on the data (e.g. annual versus daily observation)? Has the variability (and correlation) of these series changed over time? To answer these questions, means, standard deviations, coefficients of variation and correlation coefficients are calculated from the data in Figure 1 as well as from daily and annual observations of similar prices for the entire period and sub-periods from 1960 to 2012.The effects of short run trends in apparent volatility are also considered. The sub- periods considered here are the stable period of 1998 to 2005, the current period from 2006 to 2012, and the two "food crisis/ commodity boom" periods of 2007-08 and 2010-2012. Those results are shown in Table 1. (Later we will explore these measures for periods between 2005 and 2012 according to regimes defined by energy policy constraints and corn stockholding.)

[ Table 1. Crude Oil and Corn Price Volatility, 1960-2012. about here ]

Longer run mean prices are heavily weighted by lower nominal prices in the early years, and are comparable to prices realized from 1998 to 2005 . Much higher nominal prices prevail for both corn and crude oil after 2005. Correlation coefficients are similar, above 0.85 for annual and monthly measures, except for the period 1998 to 2005. During that period, when prices are quite low, correlations are lower, and decline as the frequency of observation increases. Annual corn and oil prices are correlated at 0.3, whereas the daily price correlation is negative, in 1998-2005.

The frequency of observation in cases other than the daily corn-crude oil correlation appears not to matter much to these measures of prices and their volatility. For recent prices the daily correlation is slightly lower, and since 2010 the daily standard deviation of crude oil prices is somewhat lower. Otherwise, daily, monthly and annual measures are of similar magnitudes. Since the original intent of this paper was to focus on short run volatility, we will subsequently focus on monthly measures.

The period of observations is far more important than frequency according to these results, and particularly for volatility. Standard deviations are often higher for longer periods, with some 
exceptions. These are strongly influenced by the means of sub-periods, which differ significantly. The reason to choose a coefficient of variations is that it corrects for differing means that could be due to nothing more than inflation raising the level of nominal prices. ${ }^{2}$ While some in recent literature use standard deviations to measure variability ${ }^{3}$, the coefficient of variation will be the focus here, as it corrects that problem. For the coefficients of variation for crude oil and corn, it is almost always the case that shorter periods exhibit lower volatility. The two exceptions are the 1998-2005 period for corn, which exhibited extreme stability relative to other periods, and crude oil in 2007-08. Not only have means also varied by period, so have correlations. Once again, 1998-2005 is the exceptional case.

An alternative measure of volatility would take into account effects of short run trends that give rise to large coefficients of variation, not due to random fluctuations around that trend. Standard errors around estimated short run trends were also calculated for these series to gauge this affect. For shorter periods this approach is sensitive to how well the established periods match turning points in the series. For the 2007-08 food crisis period the very strong coincident trends give rise to larger measures of apparent volatility based on coefficients of variation. For other periods this approach makes less difference. This approach does suggest that trends may have been mistaken for increased volatility in some cases.

One hypothesis then is that the apparent price volatility is influenced by trends, and by regime changes. ${ }^{4}$ The trend of rising crude oil prices from 2003 to mid-2008 is what gives rise to higher measured volatility over that period. For corn, the first (1973-74), second (1995) and third (200708) food crises, trends and regime switching led to much higher prices. This shows up in annual measures and is what makes longer run volatility seem so high. Volatility does appear to change over comparably long sub-periods, however. The volatility of corn prices for 1998-2005 was exceptionally low, as is crude oil volatility in 2010-12. As before, these are strongly influenced by change in mean prices - crude oil standard deviations are similar in 2010-12 and 1998-2005, but mean prices were much lower in 1998-2005.

From Figure 1 it is apparent that both stability and low prices of 1998-2005 were not unprecedented. Similar outcomes are observed in the 1960s and early 1990s. But judging the level and volatility of crude oil and corn prices can be distorted if short memories exclude years before 1998. Whether mechanisms determining prices before 1998 and after 2005 are similar is another matter - while the food versus fuel debate had been raised in the 1980s (Brown, 1980), the emergence of ethanol production as a large user of corn is a new phenomenon.

We will from here forward focus entirely on the period after 2005, when biofuels emerged as important to corn and energy markets. After identifying relevant sub-periods, defined by the policy constraints that bind gasoline blenders and ethanol producers, we will find similar behaviors. Mean prices will vary across sub-period and so will volatility and correlations. For shorter periods, volatility is lower, and regime switching that changes mean prices will lead to observed higher volatility. These will show up imperfectly in annual data, since crop years and 
calendar years used for EPA regulations do not coincide, and dates that legislation is passed or takes effect can influence when regimes switch (with anticipation by market participants).

\section{Ethanol Supply Chain Constraints}

Ethanol production, its use in reformulated gasoline, and the subsequent demand for corn as a feedstock, are subject to constraints along the supply chain. Some constraints have arisen due to energy legislation (RFS mandates) and EPA regulation (blend wall, MTBE substitution). Capacity constraints on production also matter to market performance, and investment in capacity is influenced by policy constraints. An important distinction is that some constraints are applied cumulatively on an annual basis - the RFS mandate applies on a calendar year basis (with some flexibility across years), not on monthly production, while others apply over the short run, such as capacity and the blend wall. Constraints that apply annually will be referred to as "stock" constraints, and among these are the condition that annual corn carry-out stocks cannot fall below zero, as anticipation of potential stock-outs can raise corn prices well ahead of when those stocks might actually fall to zero. Anticipation that other "stock" constraints may bind will influence pricing, production, stockholding, and investment in capacity. Constraints that apply instantaneously will be referred to as "flow" constraints, and include capacity constraints on gasoline as well as ethanol. This distinction is not necessarily apparent in an annual model, but matters to which constraint may actually appear to bind, and hence determine the regime under which short term prices are set. Stock constraints considered here include RFS mandates and carry-out stocks for corn. Flow constraints include capacity constraints, MTBE substitution (gasoline chemistry) and the blend wall. Flow constraints are more likely to impact production (quantities), whereas stocks constraints influence expectations, hence prices.

The history of constraints on gasoline blending and ethanol production, particularly as a result of energy legislation and EPA regulations, have been extensively documented in literature cited earlier (e.g. Tyner, 2008; Carter, Rausser and Smith, 2012). Only the critical elements determining relevant constraints during 2005-2012 are discussed below.

\section{RFS Mandates}

Legislation favoring ethanol production from corn has been debated and in place since the late 1970s (Tyner, 2008). In 2005, significant changes in legislation governing ethanol production and use were enacted. The Renewable Fuels Standard (RFS), which mandated minimum production levels for future years for ethanol, was enacted then (U.S. Congress, 2005). That legislation also included continued subsidization of ethanol production, then through a tax credit to gasoline blenders of $\$ 0.51$ per gallon (referred to as VEETC), and a tariff on imported ethanol, ostensibly to insure foreign producers did not get the subsidy, of $\$ 0.45$ per gallon plus $2.5 \%$ of imported value. The Energy Policy Act of 2007 (U.S. Congress, 2007) substantially increased RFS mandated minimum ethanol production levels for the future. The VEETC was reduced to \$0.45 during the 2007-08 food crisis, and was eliminated on December 31, 2011. The tariff on 
imported ethanol for fuel use was also cut in 2012. Numerous other federal and state policy measures influence the profitability of ethanol production, but the tax credit (subsidy), tariff, and mandates were the most significant measures among those impacting the corn market. That legislation also affects ethanol produced from feed stocks other than corn - second generation biofuels. A limit is placed on the amount of ethanol from corn that can be used to meet the various RFS mandates. Renewable Identification Numbers (RINs) are created along with ethanol production and are used to allow firm specific quotas imposed on gasoline blenders, which implement the RFS mandate, to be traded (McPhail, Westcott and Lutman, 2011). ${ }^{5}$ In principle, the market values for RINs will reflect the extent to which the RFS mandate binds as a constraint on ethanol production. Important features of this policy were the minimums on annual ethanol production from corn that went from 4 billion gallons in 2006 to 15 billion gallons in 2015, and subsidies that affect profit margins for either gasoline blenders, ethanol producers, consumers or farmers - depending on how the supply chain functions.

\section{Blend Wall}

EPA regulations limit the amount of ethanol that may be used in reformulated gasoline produced and sold by blenders. Ethanol is corrosive and may do harm in older engines, or engines not designed to tolerate high concentrations of ethanol. While modern flex-fuel vehicles can use blends including up to $85 \%$ ethanol, many vehicles can tolerate no more than $10-20 \%$ without damage. While the science on this may not be exact, the EPA had set a limit at 10\% (E10) for gasoline not explicitly marketed as E85, and recently permitted 15\% ethanol (E15) for newer vehicles. There is debate as to whether the allowed concentration can be raised without harming many existing engines, thus changing the effective limit on ethanol use. Logistical and legal issues have meant gasoline stations have been reluctant to switch toward selling E15 or even E85, so for the moment use of ethanol in gasoline is still limited to 10\%. Tyner and Viteri (2009) describe how this affects ethanol and gasoline markets, and refer to this limitation as the "blend wall". Moreover, they argue that additional logistical and other regional constraints effectively limited ethanol use to about $9 \%$ of gasoline demand, noting that this may creep upward a bit (toward 10\%) when the RFS mandate exceeds the apparent blend wall, as it did in 2012. Like the RFS mandate, this constraint is imposed on gasoline blenders, but its effects are then felt all along the ethanol supply chain. A maximum is imposed on ethanol demand for fuel use in the U.S. that is proportional to gasoline demand, but ethanol production may be affected by ethanol trade, as well.

\section{MTBE/Oxygenate Substitution}

Reformulated gasoline sold by blenders mixes "pure" gasoline bought from crude oil refiners with various additives including ethanol and MTBE. The Clean Air Act has required since the early 1990s additives to reduce carbon monoxide emissions by including an oxygenate commonly either MTBE or ethanol (Carter, Rausser and Smith, 2012). Additives such as ethanol are an alternative source of energy to "pure gas" and may also improve the chemistry of 
reformulated gasoline, for example by increasing octane or making the gas burn cleaner. Specifications of reformulated gasoline depend on both performance characteristics of additives and on EPA regulations. At lower concentrations ethanol may serve as an additive, improving gasoline chemistry, and accruing a premium, while at higher concentrations it may simply serve as an energy substitute for "pure gas". Since ethanol has fewer BTUs (less energy) per gallon than gasoline, a gallon of reformulated gasoline yields lower mileage in vehicles the larger is the ethanol concentration. If ethanol serves as an energy substitute, its pricing should reflect this difference in energy content. If ethanol serves as an additive to improve gasoline chemistry, its price may be above the energy equivalent price.

In the 1990s it was recognized that MTBE, an inexpensive by-product of crude oil refining, was toxic in groundwater (EIA, 2000). By 200625 states had banned the use of MTBE in gasoline. Gasoline blenders sought waivers from liability due to MTBE, since they were using it to meet clean air regulations. By mid-2006 it was clear that such waivers would not be granted, as MTBE liability waivers had not been part of the 2005 energy act, and subsequent related legislation failed to provide this waiver. This has encouraged blenders to use more expensive ethanol rather than face potential liability costs from MTBE use. These decisions occurred at about the same time as the RFS mandate was established, and so MTBE substitution was another factor contributing to rapid expansion of ethanol production after 2005 (Hertel and Beckman, 2012). According to the EIA (2000), reformulated gasoline meets oxygenate requirements at a 5.8\% ethanol concentration, so this may serve as a rough minimum requirement for ethanol until that concentration is exceeded. Thus, in 2006 this may have been a serious constraint on blenders, giving rise to premiums on ethanol relative to "pure gas", but by 2008 enough ethanol was produced nationally to exceed this concentration.

\section{Ethanol production capacity constraints}

The various policy measures discussed above created incentives for greater ethanol production and use as fuel. In 2005 the capacity to produce ethanol matched the small demand at that time. As demand for ethanol grew, new production capacity has been built. This occurred at a very rapid pace shortly after both the 2005 and 2007 Energy Acts. High crude oil prices relative to corn and subsidies (VEETC) insured new plants would be profitable, while the RFS mandate guaranteed a market for the output of those plants. Plant construction has stayed ahead of the RFS mandate, but the combination of the limit on corn ethanol to satisfy the mandate and the blend wall have discouraged further increases in capacity, which for corn ethanol is now at the 15 billion gallon maximum set for 2015 and beyond in the RFS. Hence, new capacity construction is now quite small (RFA, 2012). Over the period 2005-2012, our results will show that plant capacity has been the determining factor behind ethanol production and short run pricing, except for a couple of periods - briefly in late 2008 and now that the RFS mandate exceeds the blend wall. The RFS mandate and blend wall were influential over the long run in shaping this investment, but were not binding constraints on short run market performance for most of this period. 


\section{Corn Stocks}

Corn is produced/ harvested once a year but is consumed continuously over the year. Stocks allow consumption not only to be spread over a crop year, but also to be carried into the next crop year if prices are low and good production had yielded surpluses. Annual carry-out stocks cannot fall below zero, however, and in practice cannot fall below some higher pipeline level in the case of corn this may be near 5\% of use. The demand for these carry-out stocks is understood to be relative elastic when there are surpluses, but becomes quite inelastic as expected annual carry-out stocks become tight. A non-linear relationship between stocks-to use ratios and both cash and futures market prices therefore informs expectations and behaviors in agricultural commodity markets. Stocks positions have been seen as important in determining price outcomes, especially around periods of food crisis (Trostle, 2009; Wright, 2010; Carter, Smith and Rausser, 2012). In the early period when ethanol production was expanding, corn prices remained low due to abundant stocks and surpluses, but prices increased once those stocks were drawn down. In the 2011/12 crop year, low supplies led to expectations of extremely low carry-out stocks and high prices, which futures markets had indicated could fall dramatically once a good new crop is harvested. While corn prices were low in May, 2012, as the 2012/13 crop year progressed a shortfall due to drought became evident. Corn prices reached historic highs again, and stocks are unlikely to be rebuilt.

Understanding the impact of increased demand for corn to produce ethanol on corn prices requires understanding the expected stocks positions when those changes in demand occur, and its impact on that position. As Abbott, Hurt and Tyner (2011) argue, impacts of any given factor, such as biofuels demands, interact with other factors, such that two shocks can have a bigger impact that each shock might individually, especially if the two shocks together push the market into a low stocks position. If demand increases when expected stocks are high, overall demand is elastic and increased demands can be accommodated by stocks releases. When stocks are low, the corn market is much less elastic, and price increases will be higher. Persistently higher demand also eventually drove down stocks, as happened from 2005 to 2008 . One way of thinking about this relationship between annual carry-out stocks and corn prices is as if zero (or pipeline) stocks are an annual "stock" type constraint. The pricing mechanism for corn changes when stocks bind at zero, versus when they do not.

\section{Timeline of "Watershed" Periods and Related Legislation}

Table 2 presents a timeline for the events shaping development of the corn-ethanol business from 2005 to 2012. It defines "watershed periods" over which constraints shaping market outcomes may have changed. For example, the first period from July 2005 to July 2007 is referred to as the "ethanol gold rush" when high crude oil prices, low corn prices, RFS mandates and MTBE substitution all encouraged rapid construction of ethanol plant capacity. The second period, from August 2007 to July 2008 is when then corn prices then increased, in what is now called the "food crisis". The "great recession" brought an end to the commodity boom, for both crude oil 
and corn, starting by August 2008, and coinciding more closely with financial crisis than with the beginning of recession in the U.S. The NBER dates the end of the great recession as June, 2009, when another commodity boom had already restarted. By January 2010, the effects of a binding blend wall began to be apparent, but exports relieved pressure on ethanol production starting about September 2010. In 2012, after the subsidies to ethanol ended, exports slowed as well.

[ Table 2. Watershed Periods for Ethanol Related Constraints. about here ]

These watershed period distinctions are admittedly inexact. They are informed by when legislation was enacted, as indicated in Table 2, and when prices, production and trade behavior changed. Since they are informed by institutional factors such as legislation, they do not always coincide with turning points of short run trends. Figure 2 shows a graph that presents U.S. prices for corn, crude oil, gasoline and ethanol from 2005 to 2012, with the watershed periods indicated by horizontal lines at their beginning/end. Table 2 notes the changes in price trends that can be seen in Figure 2. These period definitions were also informed by the experience of observing these events and trying to understand the underlying economic forces as they occurred, as well as by the results presented later in this paper. Clear differences in mean prices as well as variances can be seen across these periods, as well as the effects of quantity adjustments due to the constraints discussed above. Those outcomes will be reported below after theory is developed to help interpret those outcomes.

[ Figure 2. Energy and Corn Prices, 2005-2012. about here ]

Setting the month when "watershed" periods begin or end presents difficulties due to anticipation of both market events and policy changes by firms. For example, the energy acts were discussed and subsequently passed in several steps, and then enacted provisions did not all apply immediately. It is also likely that firms anticipated the removal of subsidies at the end of 2011 , since that was known well in advance. Firms may make operational changes ahead of when requirements are imposed. This results in some seemingly gradual transitions as conditions change. Similarly, commodity markets anticipated the end of the great recession, so crude oil and corn prices started increasing ahead of the NBER declared end of the recession. Nevertheless, observing differences in quantities and prices in gasoline, ethanol and corn markets across these watershed periods is informative in understanding how market regimes and so outcomes may have changed.

\section{Theory on Firm/Plant Constraints}

The RFS mandates and blend wall apply directly to gasoline blenders, but effects can spill over onto ethanol producers as well as farmers. Simple theory based on profit maximization by gasoline blenders and ethanol refiners subject to constraints can inform how these constraints impact use and pricing. First, ethanol refiners and then gasoline blenders are modeled here as competitive profit maximizing actors. Results will be used understand interactions with the corn 
market and to interpret short term market data. Theory presented here also considers extensions to imperfectly competitive markets, but market conditions suggest the competitive models are more likely to be relevant.

\section{Ethanol Refiners}

Ethanol refining involves purchase of corn and natural gas to distill alcohol from the corn. Costs are mostly from the feedstock and energy, and in this model by-products will be subsumed into net other production costs for simplification. For firm or plant i, profit maximization subject to constraints can be represented as:

$$
\begin{array}{lll}
\text { Maximize } & \pi_{e}{ }^{i}=\mathrm{P}_{e} \mathrm{q}_{e}{ }^{i}-\mathrm{P}_{c} \mathrm{q}_{c e}{ }^{i}-\operatorname{Cost}_{e}{ }^{i}\left(\mathrm{q}_{\mathrm{e}}{ }^{\mathrm{i}}\right) & \text { Profit } \\
\text { Subject to } & \mathrm{q}_{\mathrm{e}}{ }^{\mathrm{i}} \leq \mathrm{k}_{\mathrm{e}}{ }^{\mathrm{i}} & \text { Capacity constraint } \\
& \mathrm{q}_{\mathrm{ce}}{ }^{\mathrm{i}}=\gamma_{\mathrm{ce}}{ }^{\mathrm{i}} \mathrm{q}_{\mathrm{e}} & \text { Leontief intermediate requirements for corn }
\end{array}
$$

where $\pi_{\mathrm{e}}{ }^{\mathrm{i}}$ is profit realized by ethanol firm/plant $\mathrm{i}$,

$\mathrm{P}_{\mathrm{e}}$ is the market price of ethanol,

$\mathrm{q}_{\mathrm{e}}{ }^{\mathrm{i}}$ is ethanol production of plant $\mathrm{i}$,

$\mathrm{P}_{\mathrm{c}}$ is the market price of corn,

$\mathrm{q}_{\mathrm{ce}} \mathrm{i}$ is the derived demand for corn by plant $\mathrm{i}$,

$\operatorname{Cost}_{\mathrm{e}}{ }^{\mathrm{i}}$ is total additional cost (beyond corn cost) to produce ethanol by plant $\mathrm{i}$,

$\mathrm{k}_{\mathrm{e}}{ }^{\mathrm{i}}$ is capacity of ethanol firm/plant $\mathrm{i}$, and

$\gamma_{\mathrm{ce}}{ }^{\mathrm{i}}$ is the quantity of corn required to produce one unit of ethanol.

Market aggregations over the $\mathrm{i}=1, \ldots, \mathrm{N}$ firms gives:

$$
\mathrm{Q}_{\mathrm{e}}=\sum_{i} \mathrm{q}_{e}^{i}, \mathrm{Q}_{\mathrm{ce}}=\sum_{i} \mathrm{q}_{c e}{ }^{i}, \mathrm{~K}_{\mathrm{e}}=\sum_{i} \mathrm{k}_{e}^{i}
$$

where $\mathrm{Q}_{\mathrm{e}}$ is market production of ethanol,

$\mathrm{Q}_{\mathrm{ce}}$ is market derived industrial demand for corn to produce ethanol, and

$\mathrm{K}_{\mathrm{e}}$ is market capacity for ethanol production.

A competitive outcome with identical firms ${ }^{7}$ yields complementary slackness conditions on capacity and rent to that capacity:

$$
\begin{array}{ll}
\lambda_{\mathrm{e}}=\mathrm{P}_{\mathrm{e}}-\gamma_{\mathrm{ce}}{ }^{\mathrm{i}} \mathrm{P}_{\mathrm{c}}-\frac{\partial \operatorname{cost}_{e}{ }^{i}}{\partial q_{e}{ }^{i}} & \text { Rent to ethanol capacity } \\
\mathrm{Q}_{\mathrm{e}} \leq \mathrm{K}_{\mathrm{e}} & \text { Market capacity constraint } \\
\lambda_{\mathrm{e}}>0 \text { if } \mathrm{Q}_{\mathrm{e}}=\mathrm{K}_{\mathrm{e}} & \text { Complementary slackness, capacity binding } \\
\lambda_{\mathrm{e}}=0 \text { if } \mathrm{Q}_{\mathrm{e}}<\mathrm{K}_{\mathrm{e}} & \text { Marginal cost determines ethanol supply }
\end{array}
$$


We shall assume for the moment that gasoline demand is large relative to ethanol demand, and that the gasoline price effectively determines the ethanol price. If capacity constraints bind, variations in the price of gasoline relative to the price of corn show up as variations in the rent to capacity $\left(\lambda_{\mathrm{e}}\right)$. If capacity constraints do not bind, if marginal "additional" cost is approximately average "additional cost" cost for ethanol production, and if ethanol production is large relative to the corn market, then variations in the gasoline price drive variations in the corn price. These are the fundamental relationships that will govern any linkage between corn and energy prices through biofuels.

The rents to capacity $\left(\lambda_{\mathrm{e}}\right)$ offer incentives for new plant construction, hence investment in expansion of ethanol production. Those rents depend on the price of ethanol (hence gasoline), the cost of corn, and other costs or revenues of plants. Policy also influences expectations that matter to investment decisions (Kesam, Ohyama and Yang, 2011).

Oligopolistic firms in either ethanol (upstream) or corn (downstream) markets would require relaxing the small actor assumptions invoked above, so that:

$$
\lambda_{\mathrm{e}}=\mathrm{P}_{\mathrm{e}}-\gamma_{\mathrm{ce}}{ }^{\mathrm{i}} \mathrm{P}_{\mathrm{c}}-\frac{\partial \operatorname{Cost}_{e}^{i}}{\partial q_{e}{ }^{i}}+q_{e}^{i} \frac{\partial P_{e}}{\partial q_{e}{ }^{i}}-\gamma_{\mathrm{ce}}^{\mathrm{i}} q_{e}^{i} \frac{\partial P_{c}}{\partial q_{c e}{ }^{i}}
$$

Rents depend on market capacity utilization (especially if firms are heterogeneous, and plant $\mathrm{i}$ is typical and not necessarily the least efficient operating firm). They may also depend on corn and ethanol market conditions captured by the conjecture on ethanol price effects $\left(\frac{\partial P_{e}}{\partial q_{e}{ }^{i}}\right)$ and the conjecture on corn price effects $\left(\frac{\partial P_{c}}{\partial q_{c e}{ }^{i}}\right)$ - hence on factors related to corn market elasticity (e.g. stocks), and demand for ethanol and so the gasoline price. If plants face binding capacity constraints, and that determines the market outcome $\left(\mathrm{Q}_{\mathrm{e}}\right.$ and $\left.\mathrm{q}_{\mathrm{e}}{ }^{\mathrm{i}}\right)$, conjecture terms are theoretically irrelevant as firms cannot adjust $\mathrm{q}_{\mathrm{e}}{ }^{\mathrm{i}}$ to influence prices.

$\mathrm{Q}_{\mathrm{e}}$ may be determined by blender demand constraints (e.g. the "MTBE/ oxygenate requirement") that supersede capacity constraints. If ethanol is simply to provide an oxygenate, its demand by blenders is a fixed concentration that still prevents $\mathrm{q}_{\mathrm{e}}{ }_{\mathrm{i}}$ from varying to maximize profit. In that case, ethanol refiners face perfectly inelastic demand. Those constraints should look like capacity constraints when they limit ethanol production, and may lead to positive rents, $\lambda_{\mathrm{e}}$. On the other hand, the blend wall minimum would lower $\mathrm{P}_{\mathrm{e}}$ offered by blenders, and with fixed quantity could give rise to negative $\lambda_{\mathrm{e}}$, or losses to ethanol, since corn demand is also fixed by the blender constraint. Understanding how blender demand relates to ethanol production requires specifying the gasoline blender's profit maximization problem.

\section{Gasoline Blenders}

In order to understand linkages between gasoline and ethanol and to see how policy constraints may spill over, it is useful to consider reformulated gasoline blending. After all, EPA enforces 
mandates and regulations on gasoline blenders, not ethanol refiners. Gasoline supply by profit maximizing blenders may be modeled as follows, assuming identical blenders aggregated to reflect market outcomes:

$$
\text { Maximize } \quad \pi_{\mathrm{r}}=\mathrm{P}_{\mathrm{r}} \mathrm{Q}_{\mathrm{r}}-\left(\mathrm{P}_{\mathrm{e}}-\tau_{\mathrm{e}}\right) \mathrm{Q}_{\mathrm{e}}-\mathrm{P}_{\mathrm{g}} \mathrm{Q}_{\mathrm{g}}-\operatorname{Cost}_{\mathrm{r}}\left(\mathrm{Q}_{\mathrm{r}}, \mathrm{Q}_{\mathrm{mbte}}\right) \quad \text { Profit }
$$

Subject to $\quad \mathrm{Q}_{\mathrm{r}} \leq \mathrm{K}_{\mathrm{r}} \quad$ Gasoline/blending capacity constraints

$$
\begin{array}{lr}
\mathrm{Q}_{\mathrm{r}}=\mathrm{Q}_{\mathrm{g}}+\gamma_{\mathrm{ge}} \mathrm{Q}_{\mathrm{e}} \quad \text { Blending ethanol and "pure gas" based on energy } \\
\mathrm{Q}_{\mathrm{e}} \geq \gamma_{\mathrm{go}} \mathrm{Q}_{\mathrm{r}}-\gamma_{\mathrm{gm}} \mathrm{Q}_{\mathrm{mtbe}} & \text { Oxygenate/octane (chemistry) constraint } \\
\sum_{t} Q_{e} \geq \mathrm{RFS} & \text { RFS-- annual minimum ethanol production } \\
\mathrm{Q}_{\mathrm{e}} \leq \gamma_{\mathrm{bw}} \mathrm{Q}_{\mathrm{r}} & \text { Blend wall maximum on ethanol in gas }
\end{array}
$$

Where $\pi_{\mathrm{r}}$ is profit realized by reformulated gasoline blenders,

$\mathrm{P}_{\mathrm{r}}$ is the market price of reformulated gasoline,

$\mathrm{Q}_{\mathrm{r}}$ is market production of reformulated gasoline (energy basis),

$\tau_{\mathrm{e}}$ is the tax credit given to blenders for use of ethanol in reformulated gasoline (VEETC),

$\mathrm{P}_{\mathrm{g}}$ is the market price of gasoline bought by blenders ("pure gas" ex refiner),

$\mathrm{Q}_{\mathrm{g}}$ is demand for reformulated gasoline from blenders,

$\mathrm{Q}_{\mathrm{mtbe}}$ is the quantity of MTBE used to fulfill oxygenate requirements,

Cost $_{\mathrm{g}}$ is total additional cost (beyond ethanol and "pure" gasoline cost) to produce

reformulated gasoline, including taxes on sales of gasoline and penalties for MTBE use,

$\mathrm{K}_{\mathrm{r}}$ is gasoline/refining/blending capacity,

$\gamma_{\mathrm{ge}}$ is the relative energy content of ethanol (as compared to "pure gas"),

$\gamma_{\mathrm{go}}$ is the blending requirement for ethanol to meet oxygenate or octane requirements,

$\gamma_{\mathrm{gm}}$ is the contribution of MTBE to meet those requirements, and

$\gamma_{b w}$ is the EPA set maximum ethanol concentration for reformulated gasoline.

This model applies on a monthly basis, but the RFS constraint applies annually. A dynamic model with this behavior repeated over the course of a year, and with any linkages across months, would need to be built to properly capture the RFS constraint. For now we simply assume each month's production is added and that sum must exceed the annual RFS mandate.

Reformulated gasoline market demand is given by:

$$
\mathrm{Q}_{\mathrm{r}}=\mathrm{Qd}_{\mathrm{r}}\left(\mathrm{P}_{\mathrm{r}} \text {, other variables }\right)
$$

Competitive blenders take $\mathrm{P}_{\mathrm{r}}$ as given at the equilibrium market price for reformulated gasoline. Competitive refiners offer gasoline at $\mathrm{P}_{\mathrm{g}}$, determined by the world price of oil and the cost of crude oil refining. We shall for now assume gasoline demand is inelastic but small relative to world energy markets, making $\mathrm{P}_{\mathrm{g}}$ exogenous. Binding refining constraints or oligopoly would 
drive a wedge between gasoline and crude oil prices. If ethanol use is small relative to gasoline demand, the price of gasoline may still be exogenous to blenders.

Some outcomes may be determined when $\mathrm{P}_{\mathrm{g}}$ is fixed, the competitive case. If no constraints bind, and gas refining as well as blending are competitive, ethanol should be priced at its energy equivalent to gasoline, plus the tax credit. In this case, the VEETC is fully passed down to ethanol refiners:

$$
\mathrm{P}_{\mathrm{e}}-\tau_{\mathrm{e}}=\gamma_{\mathrm{ge}} \mathrm{P}_{\mathrm{g}}=\gamma_{\mathrm{ge}}\left(\mathrm{P}_{\mathrm{r}}-\frac{\partial \cos _{r}^{i}}{\partial Q_{r}}\right)
$$

Blending capacity constraints would raise $P_{r}$ relative to $P_{g}$, so:

$$
\mathrm{P}_{\mathrm{e}}-\tau_{\mathrm{e}}=\gamma_{\mathrm{ge}} \mathrm{P}_{\mathrm{g}}=\gamma_{\mathrm{ge}}\left(\mathrm{P}_{\mathrm{r}}-\frac{\partial \operatorname{Cost}_{r}^{i}}{\partial Q_{r}}+\lambda_{\mathrm{r}}\right)
$$

where $\lambda_{\mathrm{r}}$ is the rent to capacity for blenders. In addition to this capacity rent, constraints related to ethanol use in blending may affect the difference between $\mathrm{P}_{\mathrm{g}}$ and $\mathrm{P}_{\mathrm{r}}$. $\mathrm{P}_{\mathrm{r}}$ will reflect any premiums or discounts accruing to ethanol relative to its energy value, and any impacts on blending costs, such as avoiding costs due to MTBE usage or liability.

If the oxygenate or octane (Chemistry) constraint binds:

$$
\mathrm{P}_{\mathrm{e}}-\tau_{\mathrm{e}}=\gamma_{\mathrm{ge}} \mathrm{P}_{\mathrm{g}}+\lambda_{\mathrm{o}}
$$

where $\lambda_{\mathrm{o}}$ is the marginal value to ethanol, beyond its energy contribution, due to the blending chemistry benefits it brings. If ethanol raises octane in reformulated gasoline, a premium should accrue to ethanol from this effect. Similarly, if ethanol meets oxygenate requirements for gasoline in lieu of MTBE, this will also contribute a premium to ethanol relative to its energy content. That premium will reflect any costs associated with continuing to use MTBE as an oxygenate, subsumed here in the additional cost function. The extent of ethanol use in gasoline will cause these premiums to vary over time. If the price of gasoline is high, and if these constraints do not bind, $\lambda_{\mathrm{o}}$ may approach zero.

The RFS mandated minimum could also generate a premium for ethanol over its energy equivalent price:

$$
P_{e}-\tau_{e}=\gamma_{g e} P_{g}+\lambda_{\text {rfs }}
$$

Like the corn stock-out condition, this constraint applies over a year (calendar year, not crop year). Hence, this premium likely would depend on expectations that the RFS may eventually bind. This premium should give rise to a positive price for corn ethanol RINS, the tradable instrument that implements this constraint for blenders. 
It is likely in a strict math program that either the oxygenate/octane or RFS constraint binds, but not both, since both are minimums on ethanol use in blending, and their being equal would be an unlikely coincidence. But the chemistry constraints are flow constraints that bind at each instant, whereas the RFS mandate is a stock constraint that binds on an annual basis. In an uncertain world, both could influence expectations and so short run ethanol prices. The RFS constraint in practice is further complicated by the possibility that RINs, hence ethanol production, may be used to satisfy the RFS constraint in the year used or in an adjacent year, as chosen by the blender subject to restrictions (Paulson, 2012). It is not in practice the strict inequality posited above.

A binding blend wall constraint puts pressure on the ethanol price in the other direction, leading to discounts on ethanol so that a maximum usage restriction is not exceeded:

$$
\mathrm{P}_{\mathrm{e}}-\tau_{\mathrm{e}}=\gamma_{\mathrm{ge}} \mathrm{P}_{\mathrm{g}}-\lambda_{\mathrm{bw}}
$$

where $\lambda_{\mathrm{bw}}$ is the discount on the ethanol constraint due to a binding blend wall. Once again, it is unlikely that a blend wall minimum and RFS or oxygenate maximum would bind simultaneously, though in recent years these constraints have moved quite close together. Moreover, if the blend wall is lower than the RFS minimum, the solution to this problem is infeasible in the absence of ethanol trade.

Key results include that ethanol prices will follow gasoline prices and so crude oil prices if blenders are competitive and chemistry or blending capacity constraints do not bind. Ethanol prices will be passed on to corn prices only if ethanol production capacity constraints do not bind. When those capacity constraints bind ethanol generates a perfectly inelastic demand for corn, and rents absorb corn versus crude oil price variations.

\section{Corn Market Implications}

In order to determine linkages between energy markets and corn, a simple model of the U.S. corn market will be developed here. That model is then used to interpret implications of the above results for corn prices, demand and volatility, as well as to assess data on prices and quantities for corn, ethanol and gasoline.

\section{Modeling U.S. Corn}

Equilibrium in the corn market equates supply with various demand components, including feed use, food use, derived industrial demand for corn to produce ethanol, and export demand:

$$
\mathrm{Q}_{\mathrm{c}}\left(\mathrm{P}_{\mathrm{c}}\right)=\mathrm{Q}_{\mathrm{cf}}\left(\mathrm{P}_{\mathrm{c}}\right)+\mathrm{Q}_{\mathrm{cs}}\left(\mathrm{P}_{\mathrm{c}}\right)+\mathrm{Q}_{\mathrm{cx}}\left(\mathrm{P}_{\mathrm{c}}\right)+\mathrm{Q}_{\mathrm{ce}}
$$

where Qc is corn supply that is fixed in the very short run and responds to price over the longer run, including beginning stocks; 
$\mathrm{Q}_{\mathrm{cf}}$ is feed, food, seed and residual demand for corn (everything in domestic use but ethanol), which is presumably relatively price inelastic, with elasticity mostly coming from feed use.

$\mathrm{Q}_{\mathrm{cs}}$ is carry-out stocks demand, which would be very elastic in periods of abundant supply (surplus) and quite inelastic in periods of short supply. Stock-out conditions could be thought of as a constraint on corn demand that sometimes binds, affecting the overall elasticity of corn demand. Stock-outs are an annual phenomenon, occurring just before next year's harvest, so in the short run expectations on this future outcome should influence the corn price. This is captured by specifying a non-linear carry-out stocks demand function as described above.

$\mathrm{Q}_{\mathrm{cx}}$ is net export demand for corn, which would be price elastic for a small country trader, but is likely inelastic for the U.S., since it accounts for over half of world corn trade in most recent years; and

$\mathrm{Q}_{\mathrm{ce}}$ is the derived demand for corn by the ethanol market. If capacity constraints are binding this is perfectly inelastic at $\gamma_{\mathrm{ce}}{ }^{\mathrm{i}} \mathrm{K}_{\mathrm{e}}$, and if capacity constraints do not bind this demand may be perfectly elastic at a price determined by the price of gasoline, $\mathrm{P}_{\mathrm{c}}=\left(\mathrm{P}_{\mathrm{e}^{-}} \frac{\partial \operatorname{Cost}_{e}{ }^{i}}{\partial q_{e}}\right) / \gamma_{\mathrm{ce}}{ }^{\mathrm{i}}$. Alternatively, $Q_{e}$ and therefore $Q_{c e}=\gamma_{c e}{ }^{i} Q_{e}$ may be determined by gasoline blending requirements, such as the RFS mandate or oxygenate rules. In those cases industrial corn demand is perfectly inelastic, as well.

Figure 3 graphically depicts this model in a two-panel diagram framework commonly used for trade analysis. In it the demand components are summed to arrive at the kinked overall demand function for corn, similar to that found in Tyner (2010) and McPhail and Babcock (2012). The demand for corn to produce ethanol includes two horizontal portions determined by the RFS mandate (minimum) and either the blend wall or capacity constraints (maximum). The novel feature here is that it is capacity constraints in the short run, not the RFS or blend wall, which will bind, determining prices. The flat portion of that demand curve, so also for the overall domestic demand curve, occurs when ethanol production falls between its upper and lower bounds, and will be higher or lower depending on crude oil/ gasoline prices, as given by the ethanol pricing relationship derived above when capacity rents are zero. Hence, there is a region where corn and gasoline prices may be directly linked, but given current constraints that is over a quite small range.

This graph is based on a simple Excel model implementing the above theory, and calibrated to fit the 2005/06 crop year using elasticities that are on the low side of those found in the literature. The shift in demand for ethanol from 2005 to 2009 is represented here as an exogenous shift to the right of corn demand for ethanol corresponding with the actual increase over that period.

[ Figure 3. Corn Supply, Use and Exports. about here ] 
Equilibrium is found here in the right hand panel that depicts foreign trade in corn. ${ }^{8}$ That is done to highlight the nature and uncertainty of foreign demand. Several cases can be seen in that graph. If the U.S. were a small country in the world market, taking the world price as given, corn exports fall to zero as the U.S. net export supply of corn shifts leftward as a result of the domestic demand increase. If corn export demand is relatively elastic, exports fall substantially with a small increase in the U.S. and so world corn price. If export demand is quite inelastic, a larger price increase follows from a smaller export decline. The result for inelastic export demand is close to several results from some more complex calibrated modeling exercises (e.g. McPhail and Babcock, 2012), with ethanol raising corn prices by about 33\%, hence from $\$ 3.00$ per bushel in 2005 to about $\$ 4.00$ in 2009 . The net export demand elasticity facing U.S. corn market has been the subject of controversy over time, with some insisting that export demand over the time frame modeled in Figure 3 (4 years) should be relatively elastic. An early study (Elobied et. al., 2007) forecasting the implications of biofuels demands found assuming relatively elastic foreign demand the implausible result that the U.S. would import corn while the world price need not rise above $\$ 4.00$ per bushel to accommodate ethanol production at more than twice levels seen in 2011/2012. Modeling results depend critically on the corn export demand elasticity as well as domestic behavioral parameters. To get bigger price impacts than are found here in the short run, very low elasticities need to be assumed - or some other driving factors need to be invoked.

\section{Prices, subsidies and volatility}

Implications for price volatility can be found from the above theory. Key relationships governing the corn market include an equilibrium condition that includes derived demand for corn based on ethanol production -- that in many circumstances is exogenous:

$$
\mathrm{Q}_{\mathrm{c}}(\mathrm{Pc})=\mathrm{Q}_{\mathrm{cf}}\left(\mathrm{P}_{\mathrm{c}}\right)+\mathrm{Q}_{\mathrm{cs}}\left(\mathrm{P}_{\mathrm{c}}\right)+\mathrm{Q}_{\mathrm{cx}}\left(\mathrm{P}_{\mathrm{c}}\right)+\gamma_{\mathrm{ce}}{ }^{\mathrm{i}} \mathrm{Q}_{\mathrm{e}} \quad \text { Corn market equilibrium }
$$

and the relationship between corn and ethanol prices, that includes rents to capacity in addition to the net marginal cost of ethanol production:

$$
\lambda_{\mathrm{e}}=\mathrm{P}_{\mathrm{e}}-\gamma_{\mathrm{ce}}{ }^{\mathrm{i}} \mathrm{P}_{\mathrm{c}}-\frac{\partial \operatorname{Cost}_{e}{ }^{i}}{\partial q_{e}{ }^{i}} \quad \text { Ethanol rents }
$$

Several cases may be identified depending on which constraint binds. For ethanol producers these include capacity constraints and the blend wall:
Case e1: $\lambda_{\mathrm{e}}=0, \mathrm{P}_{\mathrm{c}}=1 / \gamma_{\mathrm{ce}}^{\mathrm{i}}\left(\mathrm{P}_{\mathrm{e}}-\frac{\partial \operatorname{Cost}_{e}^{i}}{\partial q_{e}^{i}}\right)$
Elastic ethanol demand
Case e2: $\mathrm{Q}_{\mathrm{e}}=\mathrm{K}_{\mathrm{e}}, \mathrm{Q}_{\mathrm{e}}=\gamma_{\mathrm{go}} \mathrm{Q}_{\mathrm{r}}$, or $\mathrm{Q}_{\mathrm{e}}=\mathrm{RFS} / \mathrm{T}$
Binding production constraints
Case e3: $\lambda_{\mathrm{e}}=\mathrm{F}\left(\mathrm{Q}_{\mathrm{e}} / \mathrm{K}_{\mathrm{e}}, \frac{\partial P_{e}}{\partial q_{e}{ }^{i}}, \frac{\partial P_{c}}{\partial q_{c e}{ }^{i}}\right)$
Oligopolistic mark-ups 


$$
\text { Case e4: } \lambda_{\mathrm{e}}<0 \text { and } \mathrm{Q}_{\mathrm{e}}=\gamma_{\mathrm{bw}} \mathrm{Q}_{\mathrm{r}} \quad \text { Blend wall binding }
$$

Case e 1 corresponds with a competitively determined price for ethanol linked directly to the price of corn, or the flat part of overall corn demand in Figure 3. In that case, ethanol demand is perfectly elastic at a price driven by the price of gasoline and the cost to produce ethanol, so corn and energy prices are strongly related, the volume of ethanol production varies with those prices, and subsidies and other factors influencing the ethanol price are transmitted to the corn market. Figure 3 showed that this held over a narrow range, and more often a constraint would bind. Case e 2 corresponds with capacity constraints (maximum) binding for ethanol production. It may also represent cases where ethanol production is set by capacity constraints on gasoline blending or the RFS mandate. Ethanol production is fixed by those constraints, so exogenous to the corn market. In that case the rent to capacity absorbs variations in corn and ethanol prices, which move independently. Subsidies would not be passed to the corn market, and the effect on corn of ethanol is entirely the consequence of adding a fixed, large demand. Case e 3 shows that the rents to capacity could also be non-zero in an oligopolistic market, but quantities of ethanol produced would need to be managed (reduced) to generate these oligopolistic rents. Since there are now over 200 plants, and if ethanol production is essentially at capacity, this case is unlikely to be relevant. Case e 4 occurs when the blend wall binds, at levels below capacity. Ethanol production is fixed here by the maximum on ethanol demand by blenders, and rents can be negative in this case, reflecting the limitation on demand rather than supply. Subsequent data investigations will suggest case e 2 is the case most often encountered from 2005 to 2011 , with a brief period when case el applied. In 2011 and 2012 the blend wall appears to bind (case e4), but exports of ethanol allowed production between the blend wall and capacity. The nature and consequences of ethanol trade will be discussed later.

To investigate constraints on gasoline blenders we also need their pricing relationship:

$$
\mathrm{P}_{\mathrm{e}}-\tau_{\mathrm{e}}=\gamma_{\mathrm{ge}} \mathrm{P}_{\mathrm{g}}+\lambda_{\mathrm{x}} \quad \text { Blender pricing }
$$

Once again, several cases can be identified, based on which constraint binds:

$$
\begin{array}{lcc}
\text { Case b1: } \lambda_{\mathrm{x}}=0 & & \text { Energy equivalent pricing } \\
\text { Case b2: } \lambda_{\mathrm{x}}>0 & \text { and } \mathrm{Q}_{\mathrm{e}}=\underline{\mathrm{Q}}_{\underline{\mathrm{e}}} & \text { RFS, Oxygenate or Octane premiums } \\
\text { Case b3: } \lambda_{\mathrm{x}}<0 & \text { and } \mathrm{Q}_{\mathrm{e}}=\gamma_{\mathrm{bw}} \mathrm{Q}_{\mathrm{r}} & \text { Blend wall binding }
\end{array}
$$

In the competitive case with no binding constraints (b1) ethanol would be priced at its energy equivalent value, so the price of ethanol should follow the price of gasoline. If blending chemistry, such as premiums to ethanol as an oxygenate or octane booster, are relevant or if the RFS mandate is binding, ethanol is purchased by blenders at a premium relative to its energy value, and demand for ethanol by blenders is determined by the relevant constraint. If the blend wall limits purchases of ethanol it will sell at a discount. In each case ethanol demand, hence 
production, is fixed by a constraint. In the competitive case any subsidy $\left(\tau_{\mathrm{e}}\right)$ is transmitted from blenders to the ethanol price, and some of it may be absorbed by rents to blenders $\left(\lambda_{\mathrm{x}}\right)$ in constrained cases.

Volatility of the corn price in most cases is the consequence of a fixed, non-price responsive demand having been added to the market. Only when the two competitive cases apply (e1 and b1) will variability in crude oil prices be passed to the corn market directly via the biofuels channel. Examining market performance recently for corn will illustrate that the fixed demand cases have dominated, except during brief periods. Ethanol prices follow gasoline, subject to premiums or discounts due to constraints on blenders, largely independent of the corn price. The one factor through which ethanol most affects volatility would be that the increased demand for corn moves the market away from surplus, characterized by large carry-out stocks, and into a period in which stocks are low so that component of corn demand becomes inelastic. If corn production catches up with demand, both lower prices and lower variability should return.

\section{Corn Market Performance}

Figure 4 shows quarterly supply and use data for corn taken from the feed grains database of ERS (2012). Production is shown as a diamond at the beginning of each crop year and carry-out stocks are shown at the end. Both show substantial variability over 2005-2012. Demand is divided into demand to produce ethanol (alcohol for fuel), all other domestic demand components (feed, food, seed and other industrial uses), and exports. Both seasonality and substantially variability are seen for domestic uses excluding ethanol, and export demand is now smaller than both domestic uses, showing somewhat more variability recently. The "other use" category shows the most volatility, and has absorbed much of the increased biofuels demand, as production has not yet grown sufficiently to meet 2005 feed usage. Export demand fell from its 2007/08 peak, but is similar to 2005 levels. Demand for ethanol use is growing over this period, but at a very steady rate. Little variation around trend is seen in the derived demand for ethanol, corresponding with demand levels fixed by growing capacity to meet the RFS mandate and earlier the oxygenate requirements. That demand exhibits a flat period around the great recession (2008/09), and its trajectory slows as the RFS is nearly met and the blend wall starts to bind. This path is consistent with the notion that ethanol demand is determined in energy markets and by policy, largely independent of events in the corn market. But it is also apparent that ethanol demand has grown to be a large component of corn use.

[ Figure 4. Quarterly Corn Supply-Use Balances, Including Ethanol Demand. about here ]

\section{International Trade of Ethanol}

While there have been both imports and exports of small quantities of ethanol at least over the last decade (and before), trade became large enough to matter in 2006, when ethanol imports reached $15 \%$ of U.S. domestic production. Neither its share nor volume later reached the levels during this "ethanol gold rush" period when both MTBE substitution and the RFS mandate 
created a demand well in excess of capacity. As production capacity increased in 2007 net imports fell to $6.7 \%$ of production, and by 2009 that share was only $2 \% .2010$ saw a rise in ethanol exports and substantial two-way trade, with net exports reaching $7.6 \%$ of production in 2011, in spite of imports at levels comparable to those in 2007. High corn prices due to drought and elimination of the subsidy caused export to fall in 2012. Figure 5 plots imports and exports of ethanol against production, highlighting their small shares, apparent seasonality of trade, and the relation between price changes and trade flows. High prices in 2006, 2008 and 2009 appear to have pulled in imports later in each year, but the prices increases (and then fall) after 2009 appear more closely related to export demand.

[ Figure 5. Ethanol Trade, 2000-2012. about here ]

Figure 6 presents ethanol prices, trade unit values and margins between those prices. ${ }^{9}$ It should first be observed that margins between domestic and border prices are quite volatile. While transportation costs matter for ethanol, they are unlikely to vary to that extent. Import unit values follow domestic prices at least somewhat until 2009. The great recession and collapse of trade, and the strengthening dollar caused import unit values to fall much more than domestic prices, but cheap imports did not elicit much trade. Export unit values were remarkably stable, suggesting this was a specialty, differentiated product until 2010, when export unit values begin to closely follow U.S. domestic prices. This switch corresponds with the switch in direction of trade at about the same time.

[ Figure 6. Ethanol Iowa and Border Prices, 2005-2012. about here ]

Explaining the two way trade, and imports at a high cost in 2011, requires another differentiated product story. Ethanol imports in 2011, from Brazil and made from sugar cane, were used to satisfy second generation biofuels mandates and regional regulations that could not include corn based ethanol. They commanded a premium large enough to bring a small volume of imports from Brazil when price relatives had the U.S. exporting ethanol to Brazil as well (RFA, 2010; Cooper, 2012; Wisner, 2012). It is policy constraints that created this differentiation, not product quality.

The relationship to Brazil's ethanol industry also helps to explain the shift in trade to U.S. ethanol exports, as well. Brazil's ethanol industry is advanced, and has for a long period provided an alternative there to crude oil imports for gasoline (Valdes, 2011). Ethanol produced from sugar cane has historically been more cost-effective than from U.S. corn, yielding a price in Brazil below U.S. prices. Figure 6 also shows a short price series for Brazil (Newman, 2011) that captures this low price from the series' start in 2007 to 2009, and shows that prices in Brazil reached and then tracked U.S. prices after mid-2009 - when net trade reversed direction. During this period there have been major increases in world sugar prices and a shortfall in Brazilian sugar production, inciting a switch from ethanol to cane sugar production there. In Brazil switching from ethanol to sugar is relatively easy, and occurs when prices dictate the switch 
(Valdes, 2011). Brazil's ethanol regime is also strongly conditioned by its own policy. For example, mandates there to use ethanol were reduced over this recent period. Changes in the exchange rate between the Brazilian Real and the dollar have also significantly influenced these relative prices. A strong Real in 2011 made imports of ethanol from Brazil more expensive, and U.S. exports to Brazil cheaper. A strong dollar contributed to the low U.S. ethanol import unit values in early 2009. A better Brazilian sugar crop in the future, a change in the value of the Real, and lower world sugar prices could change the incentives now dictating the direction and magnitude of ethanol trade at the U.S. border. In 2012, some of these effects were already evident as Brazilian ethanol imports fell significantly.

Policy influenced trade in export markets in which the U.S. replaced Brazil in 2011, as well. For example, imports by the European Union are influenced by policy constraints there (Hertel, Tyner and Birur, 2010). Newman (2011) argued that the European Union took advantage of subsidies and loopholes in trade classifications that gave rise to increasing ethanol imports until 2012. Those imports were under $20 \%$ of small U.S. exports until 2010 , but over one-quarter of the dramatically larger U.S. exports in 2010 and 2011. Higher corn prices, removal of the subsidy, and tighter trade regulations led to EU ethanol imports falling over 40\% in 2012. In 2011 EU imports were two-thirds of Brazilian imports, and only $2.1 \%$ of U.S. ethanol production when exports peaked.

Imports into the U.S. have also benefited from provisions of the Caribbean Basin Initiative that allowed duty-free ethanol imports under a tariff rate quota. The quota under that agreement has never been reached, however (Newman, 2011).

Ethanol exports in 2011 appear to have benefited from the VEETC, so production approached capacity, domestic demand remained at the "blend wall", and exports made up the difference. In 2012, after the subsidy was eliminated, export margins increased and ethanol prices fell. Production appears to have fallen near the RFS mandate while exports make up the difference between that lower production level and the blend wall.

One trade-related question concerns whether the subsidy to ethanol use (VEETC) is also paid to foreigners. The tariff on ethanol was intended to prevent (actually counteract) the subsidy from being paid to foreigners, and some have argued that it was more than sufficient to accomplish that when ethanol was primarily imported. No such provisions prevent exports from receiving the subsidy, so long as the ethanol passes through blenders and contains a small amount of gasoline. While the RFA has argued that exports do not receive a subsidy as blended products are not exported, industry analysts have argued otherwise, and trade data are not sufficiently differentiated to tell. The small margin between the domestic price of ethanol and export unit values, that increased once the subsidy was removed, also suggests exports have received at least some of the subsidy, consistent with theory presented above so long as exporters buy ethanol from blenders not ethanol refiners. 
Another question is what modeling approach should be used to capture ethanol trade, and should that be used to revise the theory elaborated above? The volatility of margins suggests any short term model relying on the law of one price (i.e. standard trade price linkages) is bound to fail. That theory gave rise to the prediction of the U.S. importing corn due to ethanol (Elobeid et. al. 2007). Armington approaches based on domestic-international differentials will also miss much of the detail of trade, such as the change in direction of trade, two way trade in 2011, and the emergence of newly large trade flows in 2006. Armington specifications will hold trade near the status quo. Elobeid and Tokagoz's (2008) trade model that incorporates both imperfect transmission of prices and an Armington-like net demand function misses the switch from imports to exports by construction. It has been argued that ethanol programs were created to meet domestic policy goals, and trade levels are a residual response to shortages or surpluses arising from those programs (Newman, 2011). An example is U.S. exports in 2011, necessitated by a binding blend wall and the need to meet a larger RFS mandate, or constrained by capacity. This suggests old "vent-for-surplus" trade models. Trade flows have also arisen to capture profits from loopholes in policy regimes, such as differing tariff definitions and opportunities to benefit from subsidies (as in trade with the EU). While trade flows have emerged in response to international price signals, the resulting flows have been just too small to fully arbitrage large price differentials. It is therefore likely that it is necessary to examine effects of trade on ethanol pricing separately under different trade regimes. What worked for the period of high imports will be likely to fail in the period of high exports. The magnitudes of trade flows remain relatively small compared to domestic markets. Domestic events in trading partner economies are also important to explaining those trade flows, especially in Brazil.

\section{Evidence over Watershed Periods}

Monthly quantity and price data for ethanol are examined over the "watershed periods" between 2005 and 2012 as defined in Table 2. Quantity data is compared to capacity, RFS mandate, blend wall, and MTBE substitution constraints. Price data is used to determine profit margins for ethanol refiners and gasoline blenders as well as to examine price volatility and correlations over these sub-periods.

\section{Quantities - Ethanol Production}

Figure 7 plots monthly ethanol production expressed as an annual flow. Capacity data in that graph are approximated from observations reported by RFA (2012) in January of each year and by assuming a linear trend between each year's observation on capacity. The RFS mandate applies on a cumulative annual basis, with bars on the graph showing the target level over the course of the year, and diamonds indicating the year end mandated minimum use. The blend wall is approximated here at 9\% of gasoline production (from Tyner and Viteri, 2010 - and as they suggest, the binding blend wall may now be closer to 10\%). The MTBE/ oxygenate substitution requirement is at $5.8 \%$ of gasoline production based on the reformulated gasoline specification (EIA, 2000). Each of these is an approximation to the actual restrictions on gasoline blenders. 
[ Figure 7. Ethanol Production, Capacity and Policy Constraints, 2000-2012. about here ]

It is apparent from Figure 7 that capacity constraints bind most often, and appear to determine production in most months. The ethanol production line lies on top of the capacity approximation except for a couple of brief but notable periods. While capacity in 2005 was below the RFS mandate for 2006, during the ethanol gold rush period capacity was increased to stay above the mandated minimum. Except in 2008, following the dramatic increase in the RFS mandate in the 2007 Energy Act, capacity exceeded the mandate by January of the year to which it would apply. In 2008 it took four months to get ahead of the RFA, and then the collapse of oil, gasoline and corn prices after recession and financial crisis in mid- 2008 brought ethanol production below capacity. Ethanol profitability fell to its lowest level during this one period when production was obviously below capacity. In mid-2009 production had risen to capacity and was sufficient to meet the RFS mandate, and over 2010 production was slightly above capacity. Industry analysts argue that optimization of plant operations now (and in 2010) allows them to operate above nameplate capacity - the figure reported by RFA - for sustained periods, and this data is consistent with that claim. ${ }^{10}$ In 2011, when the blend wall was imminent, and then when exports allowed production above the blend wall, production flows at or slightly below reported capacity are probably below actual capacity. It is apparent from this data that the RFS mandate may have shaped investment in capacity, but it only threatened to constrain production in early2009, and this is the one period when RINs were not effectively zero. Moreover, from 2000 to 2011 production has been essentially at capacity, except during that period in early 2009, and fell below capacity again in 2012. This smooth, constrained growth in production generated similarly smooth growth in demand for corn as a feedstock to ethanol production.

The MTBE/ oxygenate substitution requirement was not met by ethanol production until late 2007. The need to meet that requirement surely helped to spur investment during the gold rush period, but was no longer binding as the food crisis set in and afterwards. The blend wall maximum on usage began to bind in early 2010, but production exceeded this constraint soon afterwards. Trade data show that from mid-2010 onwards ethanol production could remain above the blend wall as surpluses were exported. The effects of these two constraints are more apparent in prices and profitability margins than they are in quantities.

During the initial gold rush watershed period, the RFS mandate and MTBE substitution both shaped investment in capacity, which in turn dictated production. During the food crisis period, MTBE substitution was no longer binding, and the increased RFS mandate evoked large increases in capacity, which once again determined production. The great recession and collapse of commodity prices brought production briefly below capacity. Recovery and a renewed commodity boom brought production back to capacity until the blend wall and drought threatened to limit production. But in 2010 onwards exports have allowed production to exceed the blend wall at a level near capacity. Changes in circumstances in Brazil and the end of subsidies captured by exporters limited export demand for ethanol and made simultaneously meeting the blend wall (at E10) and the RFS mandate infeasible without exports. One can see 
evidence of that in 2012. As conditions in world sugar markets changed and Brazil realized a better sugar crop, U.S. ethanol exports have declined, leading to idled capacity and a more severely limiting blend wall.

\section{Prices, Margins and Profits}

Prices for ethanol, corn, gasoline and crude oil shown in Figure 2 are averaged over the watershed periods in Table 3 . That figure shows ethanol prices peaking during the gold rush period, remaining high during the food crisis, and then falling until export demand and high energy prices caused ethanol prices to peak again in 2011. Crude oil and gasoline prices rose through the food crisis, fell rapidly during the great recession period, and have been generally rising for each period afterwards. Corn prices are somewhat less regular. They were low until the food crisis period, when they trended upward rapidly, then fell rapidly during the early part of the great recession period. They remained at levels that were low relative to the food crisis, but higher than pre-crisis levels until the export relief period saw high corn prices - precisely when one might have expected those higher corn prices and hence higher ethanol costs to discourage production and exports.

\section{[ Table 3. Energy and Corn Prices by Watershed Period. about here ]}

It is useful to compute profit and trade margins from the gasoline and corn prices discussed above in order to see the incentives to ethanol production. Moreover, these margins reflect the constraints that define each period. Figure 8 presents profit margins for ethanol refiners over variable costs as calculated by Hofstrand (2012) using ethanol and corn prices for representative plants in Iowa. It also presents margins for gasoline blenders buying ethanol, relative to strict energy based pricing, adjusted for the VEETC subsidy. These margin as well as the trade margins shown in Figure 6 are averaged over the watershed periods in Table 4.

[ Figure 8. Ethanol Margins relative to Corn and Gasoline, 2005-2012. about here]

[ Table 4. Ethanol Margins by Watershed Period. about here ]

Ethanol production margins over variable cost (rents $-\lambda_{\mathrm{e}}$ ) are positive in every period, but lowest once the subsidies ended in 2012. These margins were highest during the early gold rush period, when both the RFS mandate and MTBE substitution called for greater capacity. They were lower as corn prices increased during the food crisis, and lower still during the great recession period, when production briefly fell below capacity. Figure 7 shows that these margins were quite low in late 2008, but never went negative and subsequently showed seasonal peaks late in each subsequent year. Rising gasoline prices raised margins in the restarted commodity boom, but pressure from the imminent blend wall then lowered these margins. In late 2011 and early 2012, the export relief period, high crude oil and gasoline prices counteracted the higher corn prices, yielding positive margins to ethanol production. When drought in 2012 brought even higher corn prices, margins fell. 
Prior to the gold rush period, ethanol was priced below its energy value, but the need to use ethanol as an MTBE substitute led to the largest observed blending margins in 2006-07. During the food crisis this margin $\left(\lambda_{x}\right)$ turned negative again as MTBE substitution requirements were exceeded, in spite of the subsidy, and became quite negative as the blend wall constraint approached. As export demand and high oil prices caused the demand for ethanol to increase, these margins turned positive, but fell once the subsidy was removed. Changes in these data crudely suggest only $\$ 0.15$ of the $\$ 0.45$ subsidy was found in margins to blenders, with the remainder passed through to the ethanol price. Margins relative to energy cost are always smaller than the margins accruing to ethanol refiners, consistent with ethanol prices more often following gasoline prices than corn prices. RINs are even smaller, and only above $\$ 0.03$ during the food crisis and great recession, when production briefly fell below capacity. This again was likely driven by greater variations over this period in crude oil and so gasoline prices, with corn prices sustaining a higher level after the great recession than before the food crisis.

What is notable about trade margins is that they are driven by switches in the predominant direction of trade flows and by product differentiation. The differential between exports and domestic prices fell to its lowest level when exports became significant, and an outlet for domestic surpluses, during the export relief period (excluding an anomaly in the gold rush period). Export prices had become close to, and related to, domestic ethanol prices only during this export relief period. When subsidies ended in 2012, export margins increased nearly $\$ 0.37$ (ITC, 2012), suggesting exports received only a portion of the subsidy, smaller than the portion accruing to blenders. In the case of imports, the margin in the later periods reflects the premiums accruing to imports that meet the second generation RFS mandate, not the corn ethanol mandate.

\section{Volatility and Correlation}

Data on price volatility and correlations across watershed periods further highlight the importance of mechanisms related to constraints on ethanol refiners and gasoline blenders. Table 5 reports coefficients of variation computed from monthly price data for the watershed periods of 2005-2012. Table 6 reports correlation coefficients for prices over these sub-periods. ${ }^{11}$

[ Table 5. Price Volatility by Watershed Period. about here ]

[ Table 6. Price Correlations by Watershed Period. about here ]

Over the entire 2005-2012 period, volatility as measured by coefficients of variation was much lower for crude oil but comparable for corn, relative to volatility from 1960 to 2012. Once again, shorter sub-periods yield lower volatility. Trends during sub-periods generate much of observed volatility, and differences in price levels are explained by differing circumstances during each of the watershed periods. Remarkably low coefficients of variation are found for watershed periods, especially after the end of the great recession. Corn is an excellent example. In each sub-period after the great recession the coefficient of variation is less than 0.15 , while it was above 0.4 for both 1960 to 2012 and 2005 to 2012 . Volatility is also lower for gasoline prices than for crude oil 
or corn prices, and that carries over to ethanol prices. The food crisis and great recession exhibited the greatest volatility for all prices, characterized by strong upward coincident trends during the food crisis and rapid collapse of prices shortly afterwards. This led to a misperception that volatility had increased. These data are also not consistent with the notion that the high price volatility observed from 2007 to 2009 has persisted in more recent years. That there are several sub-periods since 2009 contributes to these low sub-period volatility measures. Had we measured volatility without trying to understand the changing economic mechanisms (see measures for mid-2009 to 2012 in Table 5), we would have found higher volatility, comparable to what is found during the food crisis period. But changes in means and short run trends explainable by economic conditions led to this apparent volatility, and these measures remain generally smaller than those found for the longer periods, 1960-2012 and 2005-2012.

Similar to volatility, correlations of corn and energy prices are higher over longer periods of time than they are over sub-periods. Also, correlations vary across sub-periods in ways that are broadly consistent with changing economic mechanisms as explained above, with some anomalies. For example, the correlation between ethanol and corn prices should be lower when capacity constraints bind (case e2) than during periods when capacity rents are low and these prices are linked by refiner pricing decisions (case e1). Ethanol and corn prices over 2005 to 2012 are correlated only at a coefficient of 0.53 , and this measure was lower during the gold rush and restarted commodity boom periods. As the blend wall became imminent and then exports relieved the blend wall constraint, as expected correlations when capacity may not bind are higher, above 0.7 . The anomaly to this logic is the food crisis and great recession periods that are characterized by strongly rising and then falling trends. The high correlations, over 0.9 for these periods, may reflect other forces that drove the trends, rather than these biofuels mechanisms. Capacity constraints were non-binding only briefly over these periods.

The ethanol-gasoline price correlation exhibits similar patterns. It is higher over the entire period than over several sub-periods. When the blend wall became imminent, and the rent to that constraint increased, this correlation actually turned negative. This correlation was also much higher during the food crisis and great recession than for other periods, again reflecting the strong trends. The correlations of the margin between gasoline and ethanol prices are also highly correlated with the profit margin of ethanol refiners in periods when the blend wall binds.

A somewhat surprising aspect is that crude oil-corn prices correlations are higher for the overall period and for several sub-periods, than are the correlations directly related to the biofuels mechanism. This also suggests other factors beyond biofuels contribute to this correlation. But the lowest crude oil-corn correlations do occur in recent sub-periods when the correlation between gasoline and crude oil prices is weaker. 


\section{Conclusions}

Increasing ethanol production since 2005 has led to a large, persistent, new demand for corn that has contributed to higher corn prices and sometimes tighter links between energy and agricultural prices. Constraints that arose from energy legislation and EPA regulations have shaped the trajectory of the derived demand for corn to produce ethanol, and determined mechanisms dictating the short run relationships across prices. The influence of specific regulations has varied over time - substitution of ethanol in place of MTBE was an early factor in 2006 while the blend wall limit on concentration of ethanol in gasoline is now more important. While each of these factors has surely mattered to the evolution of ethanol and corn markets, it is constraints on production capacity that have determined corn demand and pricing relationships over the short to medium run during most of the period from 2005 to 2012.

Capacity constraints are what have generally bound, determining ethanol production and hence derived demand for corn, except briefly in late 2008-09 and again in 2012. Energy policy (RFS, MTBE and blend wall) influenced capacity increments, shaping incentives to invest, but haven't strictly bound ethanol refiner behavior to date. Capacity has always remained somewhat ahead of the RFS mandate, and investment slowed as the mandate maximum on corn ethanol approached and the blend wall was reached. Exports relieved pressure from the blend wall in 2011 and allowed a solution to meeting the infeasible problem of satisfying an RFS mandated minimum above the blend wall determined maximum. How we get around the blend wall is important to the future - with the corn based RFS mandate met, some second generation mandates were waived, and the blend wall was binding, so new construction of corn ethanol plants has slowed dramatically. Large exports were possible due to circumstances in Brazil. High world sugar prices, a sugar production shortfall, and a strong currency caused Brazil to shift from a large exporter to an importer of ethanol, but those circumstances are unlikely to persist over the longer term. Lower exports were already evident in 2012.

Two mechanisms stand out as key in this analysis as a consequence of binding capacity constraints. Rents to capacity allow independent variation of gasoline (hence ethanol) and corn prices. Smoothly trending capacity has in most months determined demand for corn, leading to a perfectly inelastic demand component to satisfy biofuels needs.

When capacity constraints bind, corn and crude oil prices can live independent lives. Ethanol profit margins vary as these prices vary, and have yielded positive profits except during subperiods when capacity constraints don't bind. During those periods, crude oil price volatility is not passed directly to the corn market via the biofuels mechanism. When we are between constraints, in theory corn and crude prices are directly linked. But that is a small window - that opened only in late 2008 to early 2009, and recently. Data on price variability, correlations and profit margins are largely consistent with this theory over the short term. 
With ethanol capacity constraints binding, industrial demand for corn to produce alcohol is inelastic but not highly variable around its increasing trend. Its effect on corn markets is through the increased, persistent but stable demand. Corn stocks and the capacity to produce enough corn to meet that demand determine the corn price regime, hence variability. Ethanol contributes a large, inelastic demand component, and drove us to a low stocks state when corn production was unable to catch up with demand.

Now the combination of the blend wall and RFS are infeasible without trade or use of RINs. Exports have relieved pressure from the blend wall, but with plants now operating below capacity, profit margins for ethanol are lower. Subsidized exports in 2011 were the difference between production near capacity and the blend wall. That exports have not vanished with high corn prices reflects the importance of the blend wall now. Once subsidies were removed, export margins increased, ethanol prices fell, export demand declined, and production fell to nearer the RFS mandate. Prices of corn and ethanol are more strongly linked under this circumstance.

Flow constraints, such as capacity and the blend wall, directly impact quantities and determine production, whereas the effects of stocks constraints, such as the RFS mandate and corn carryout stocks, have had noticeable effects on prices, even if they didn't strictly bind. Stocks constraints have worked through expectations, which in turn influenced pricing.

Volatility has varied as the regime determining corn prices has changed. Short term volatility has been small, and regime changes or trends lead to larger apparent long run volatility as seen in annual data. Strong, coincident short run trends, particularly in 2007-08, led to a misperception that volatility had permanently increased. It is the big moves, not noise around long run equilibrium, which gave rise to observed volatility. From this perspective, it is high prices, not greater volatility, which defines the current era.

While the expanding biofuels demand has surely mattered to the high prices for corn and other agricultural commodities, the simple longer term model here yields effects comparable to many other factors found in the literature. While that demand may have raised corn prices by about $33 \%$ from 2005 to 2009 , to get both price and volatility results required that this effect be combined with others that moved the corn market to a position of low stocks. Such price effects can seldom be judged in isolation. For example, if/when production catches up to this demand lower corn prices, and so lower biofuels demand impacts, are expected. To get the high short term prices observed for agricultural markets recently, either much lower short term elasticities must be assumed, or other factors contributed to market outcomes.

In the future, modifications to energy policy, trade adjustments, and capacity investment will determine the role biofuels play in shaping agricultural commodity prices. Expansion from the corn mandate is finished and progress on second generation biofuels is not evident. But reliance on trade to get around the blend wall is a strategy likely to contribute to lower prices in the future. 


\section{Figures and Tables}

Figure 1. Corn and Crude Oil Prices, 1960-2012.

Figure 2. Energy and Corn Prices, 2005-2012.

Figure 3. Corn Supply, Use and Exports: A Two Panel Diagram.

Figure 4. Quarterly Corn Supply-Use Balances, Including Ethanol Demand.

Figure 5. Ethanol Trade, 2000-2012.

Figure 6. Ethanol Iowa and Border Prices, 2005-2012.

Figure 7. Ethanol Production, Capacity and Policy Constraints, 2000-2012.

Figure 8. Ethanol Margins relative to Corn and Gasoline, 2005-2012.

Table 1. Crude Oil and Corn Price Volatility, 1960-2012.

Table 2. Watershed Periods for Ethanol Related Constraints.

Table 3. Energy and Corn Prices by Watershed Period.

Table 4. Ethanol Margins by Watershed Period.

Table 5. Price Volatility by Watershed Period.

Table 6. Price Correlations by Watershed Period. 
Figure 1. Corn and Crude Oil Prices, 1960-2012.

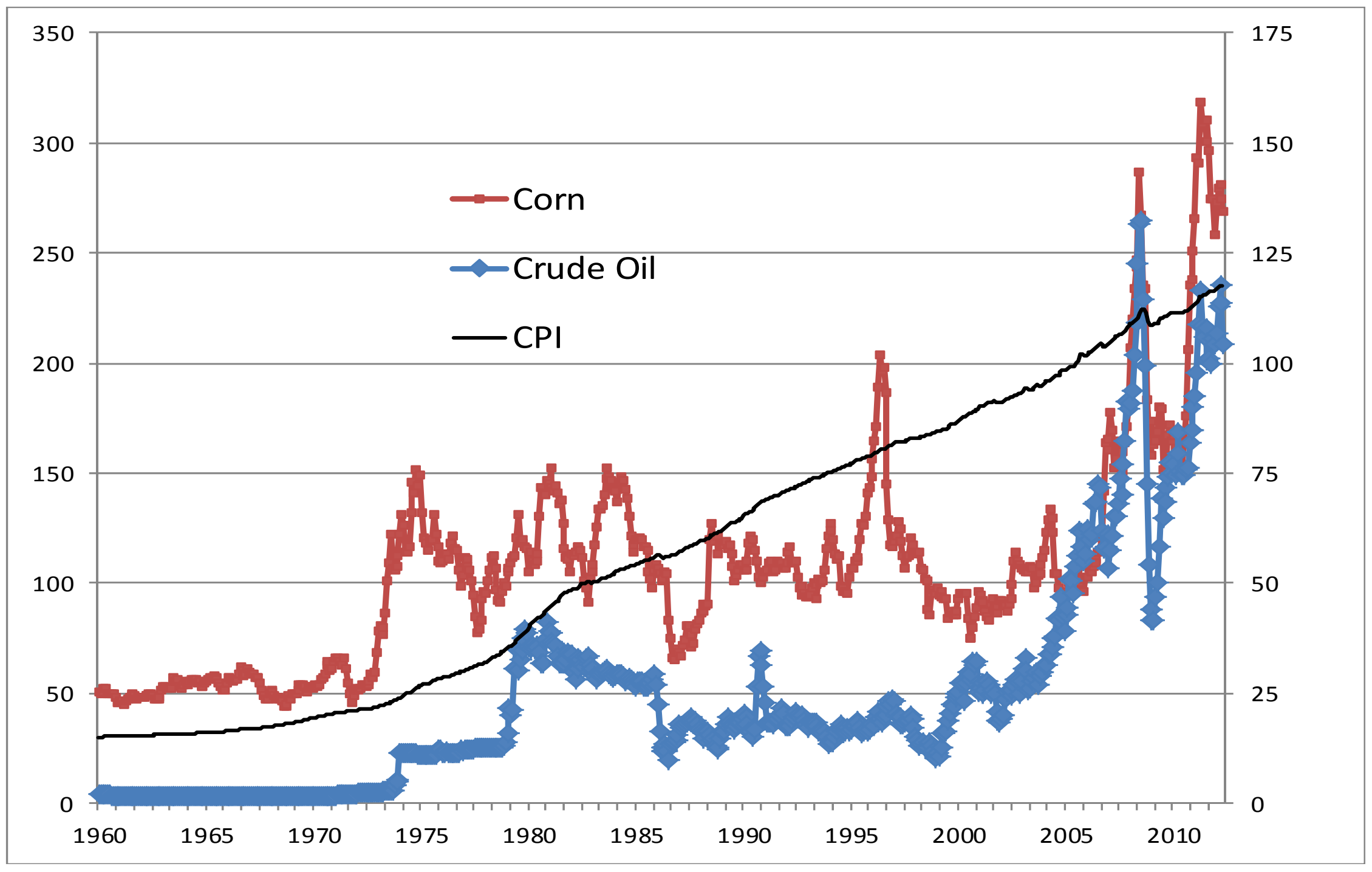

Source: Commodity Price Statistics, IMF 2012. 
Figure 2. Energy and Corn Prices, 2005-2012.

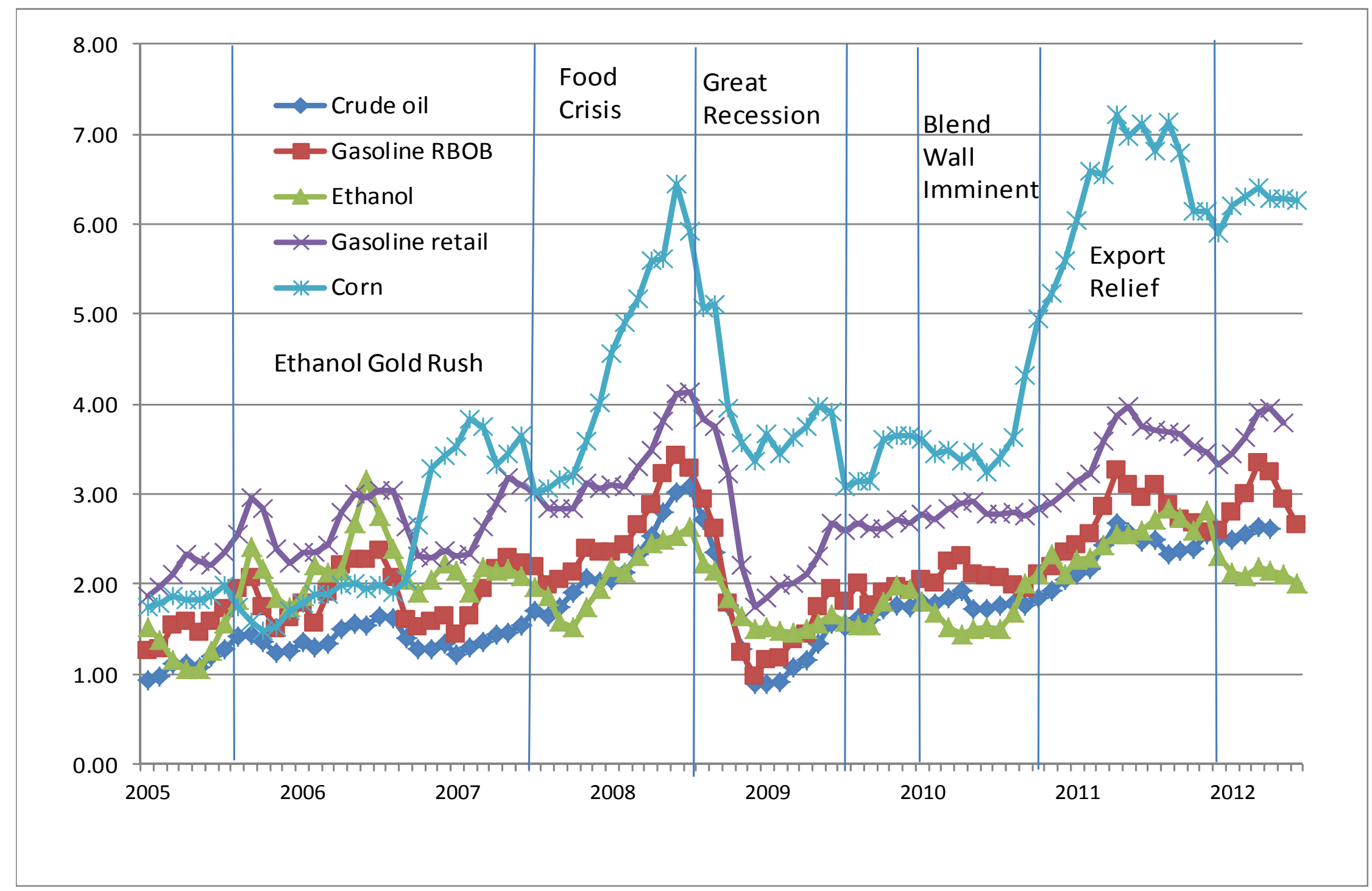

Sources: EIA,2012; Hofstrand, 2012. 
Figure 3. Corn Supply, Use and Exports: A Two Panel Diagram.

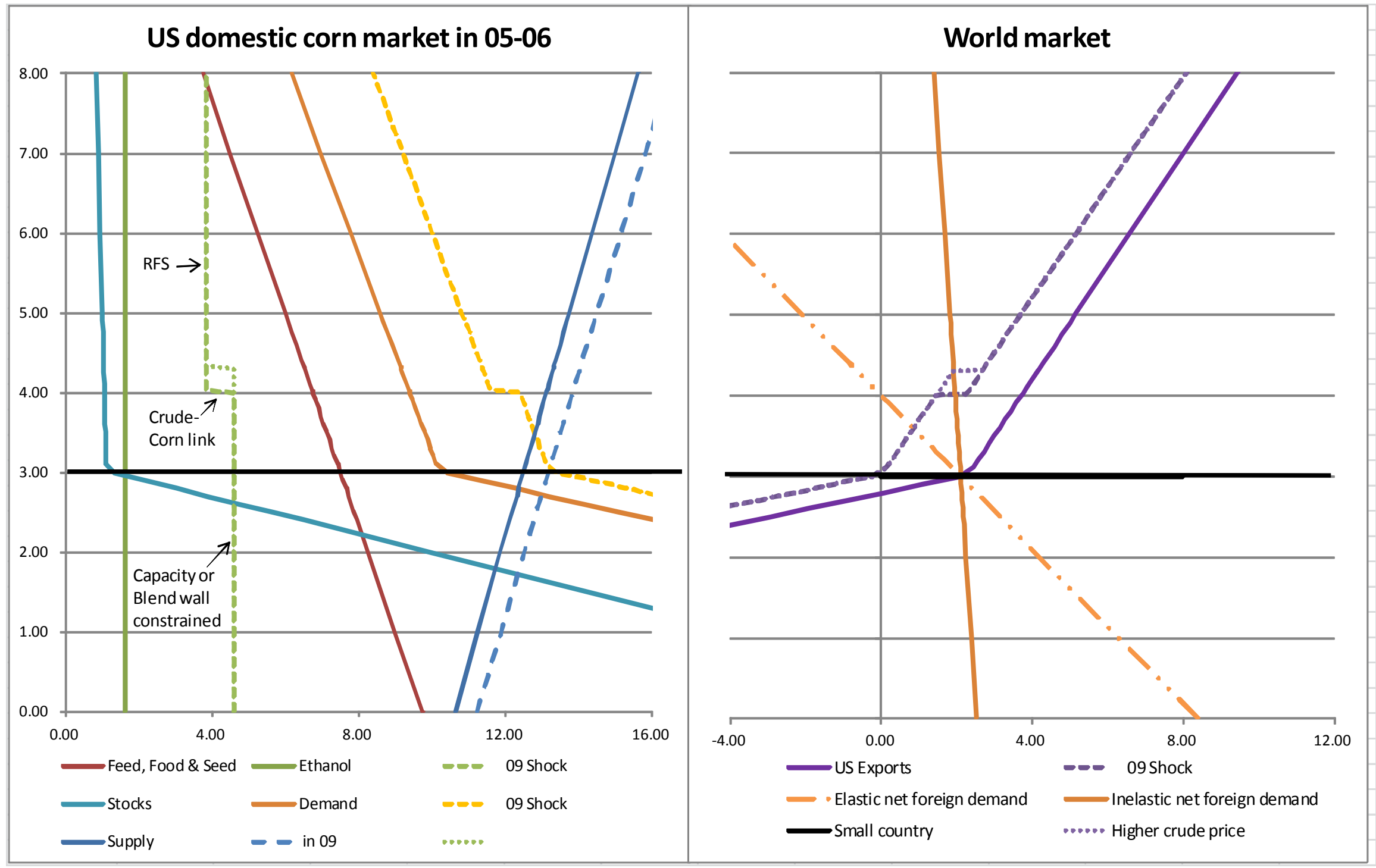


Figure 4. Quarterly Corn Supply-Use Balances, Including Ethanol Demand.

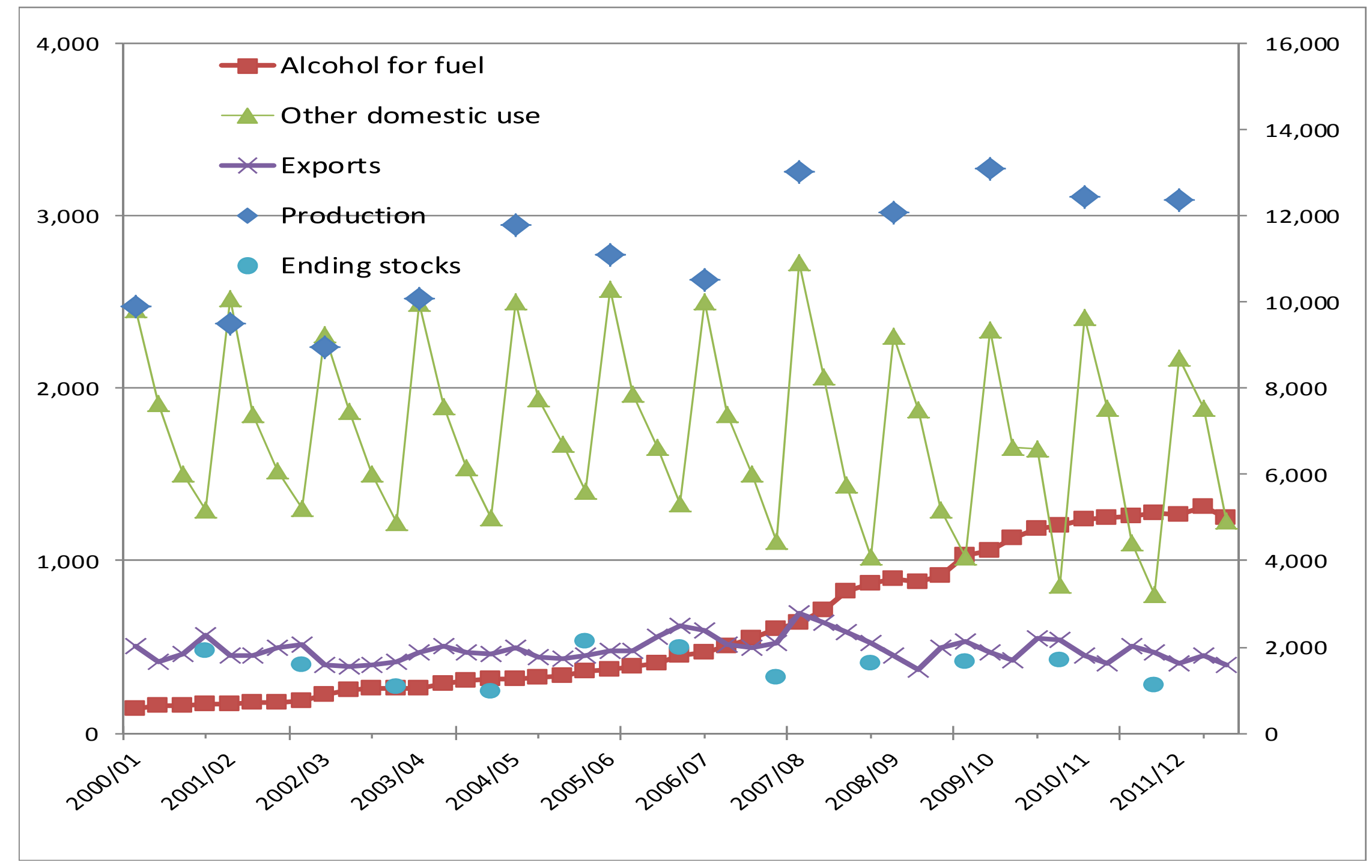

Source: ERS, 2012. 
Figure 5. Ethanol Trade, 2000-2012.

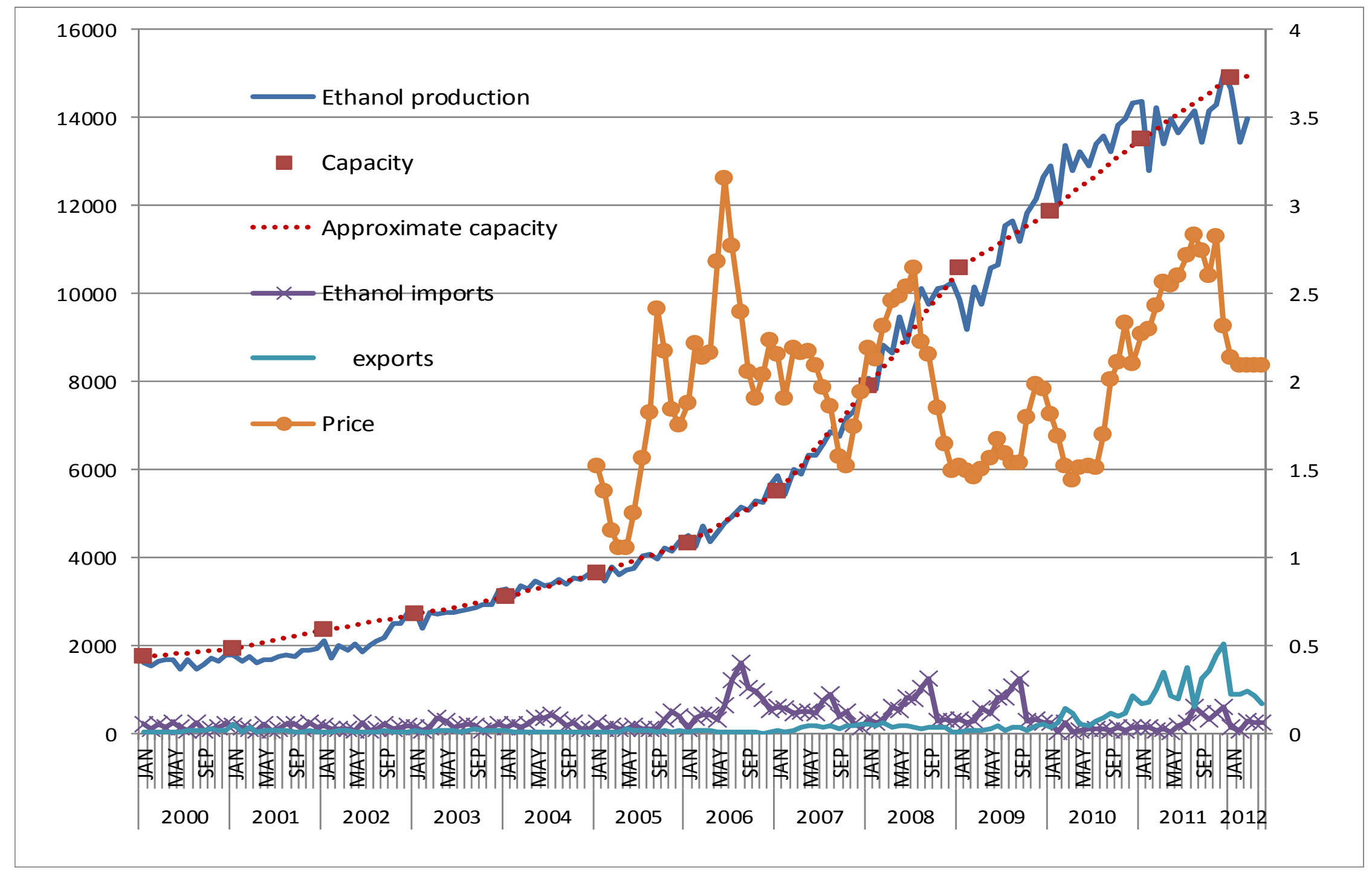

Sources: RFA, 2012; ITC, 2012; Hofstrand, 2012. 
Figure 6. Ethanol Iowa and Border Prices, 2005-2012.

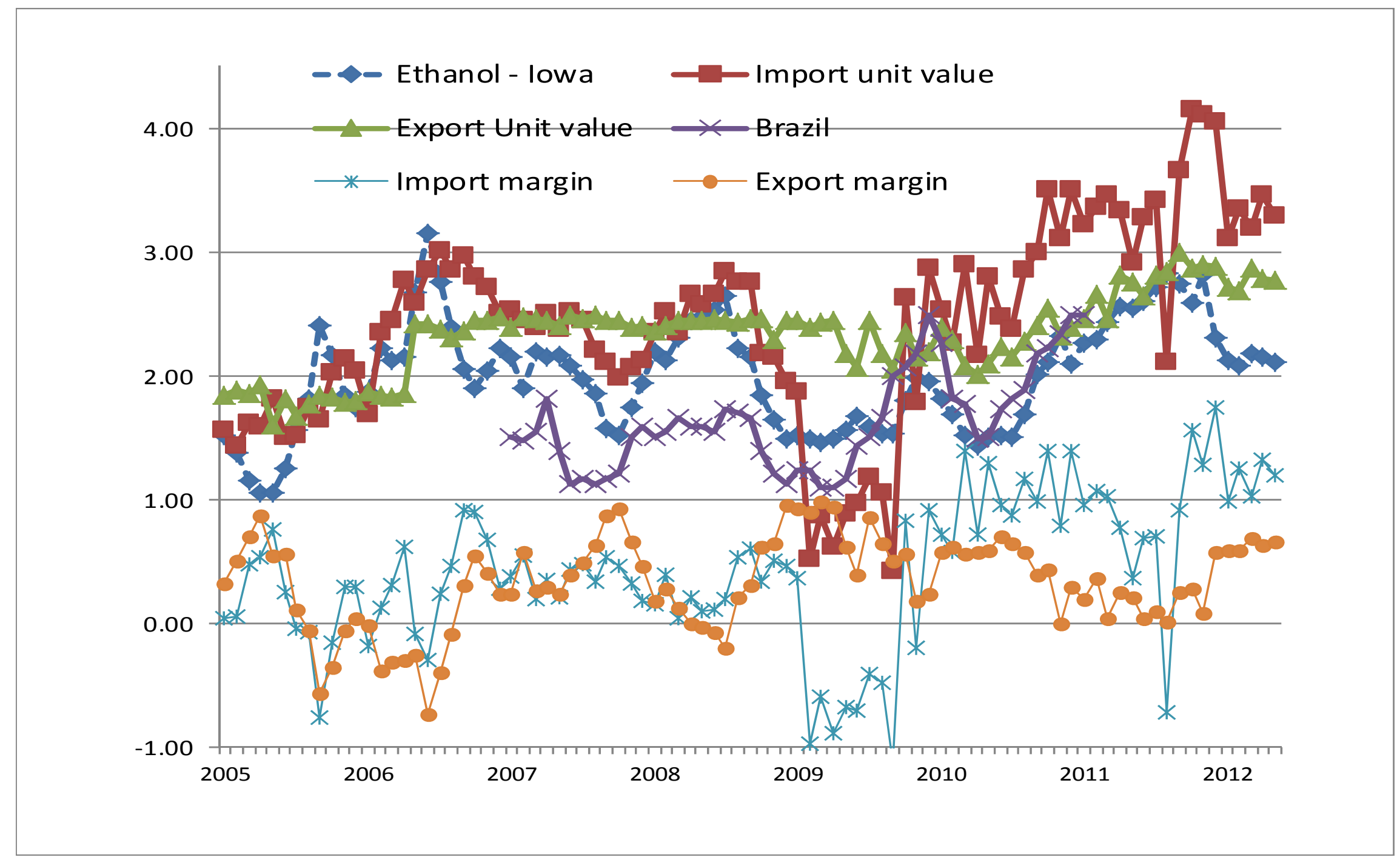

Sources: Hofstrand, 2012; ITC, 2012; Newman, 2011. 
Figure 7. Ethanol Production, Capacity and Policy Constraints, 2000-2012.

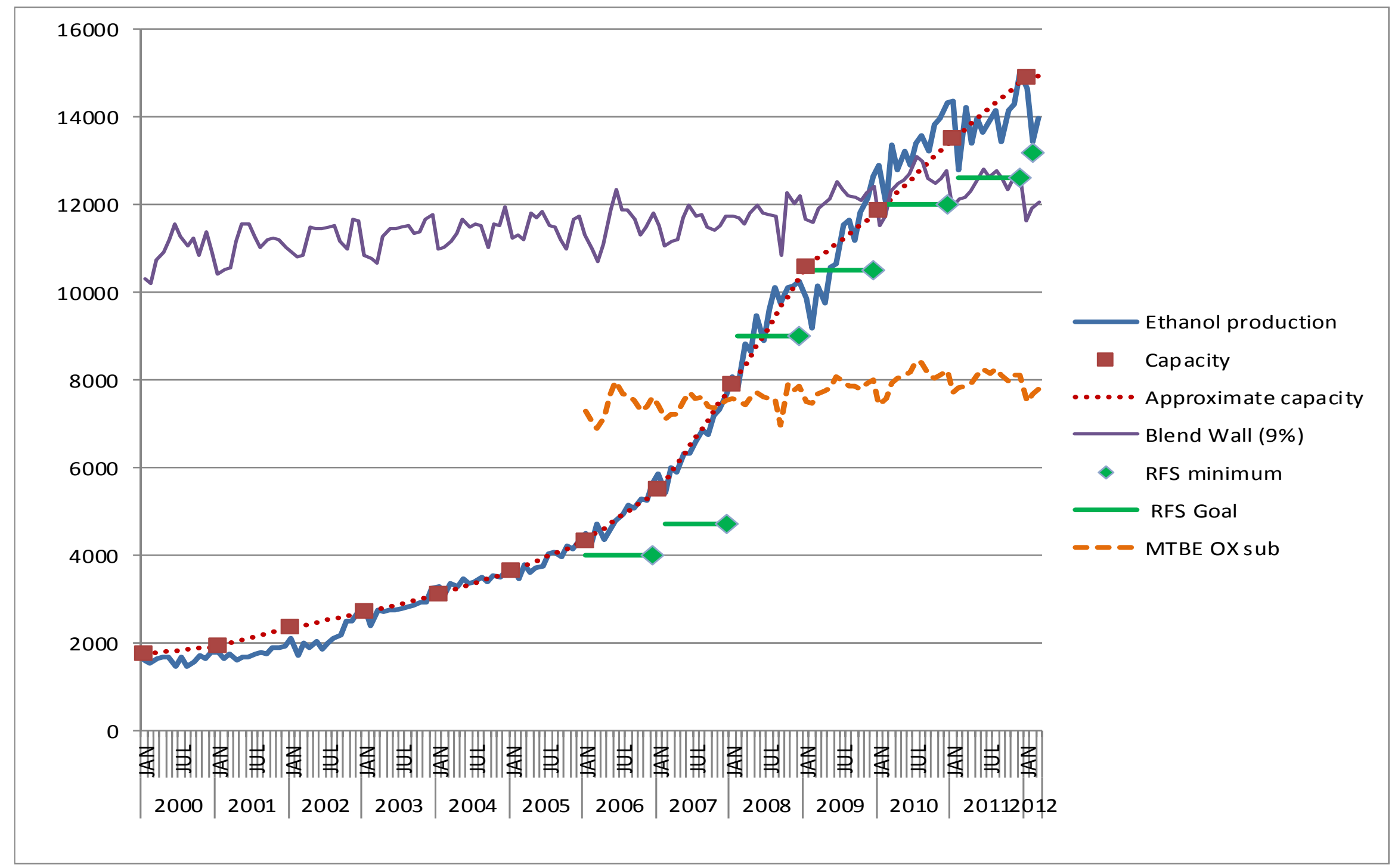

Sources: EIA, 2012; RFA, 2012. 
Figure 8. Ethanol Margins relative to Corn and Gasoline, 2005-2012.

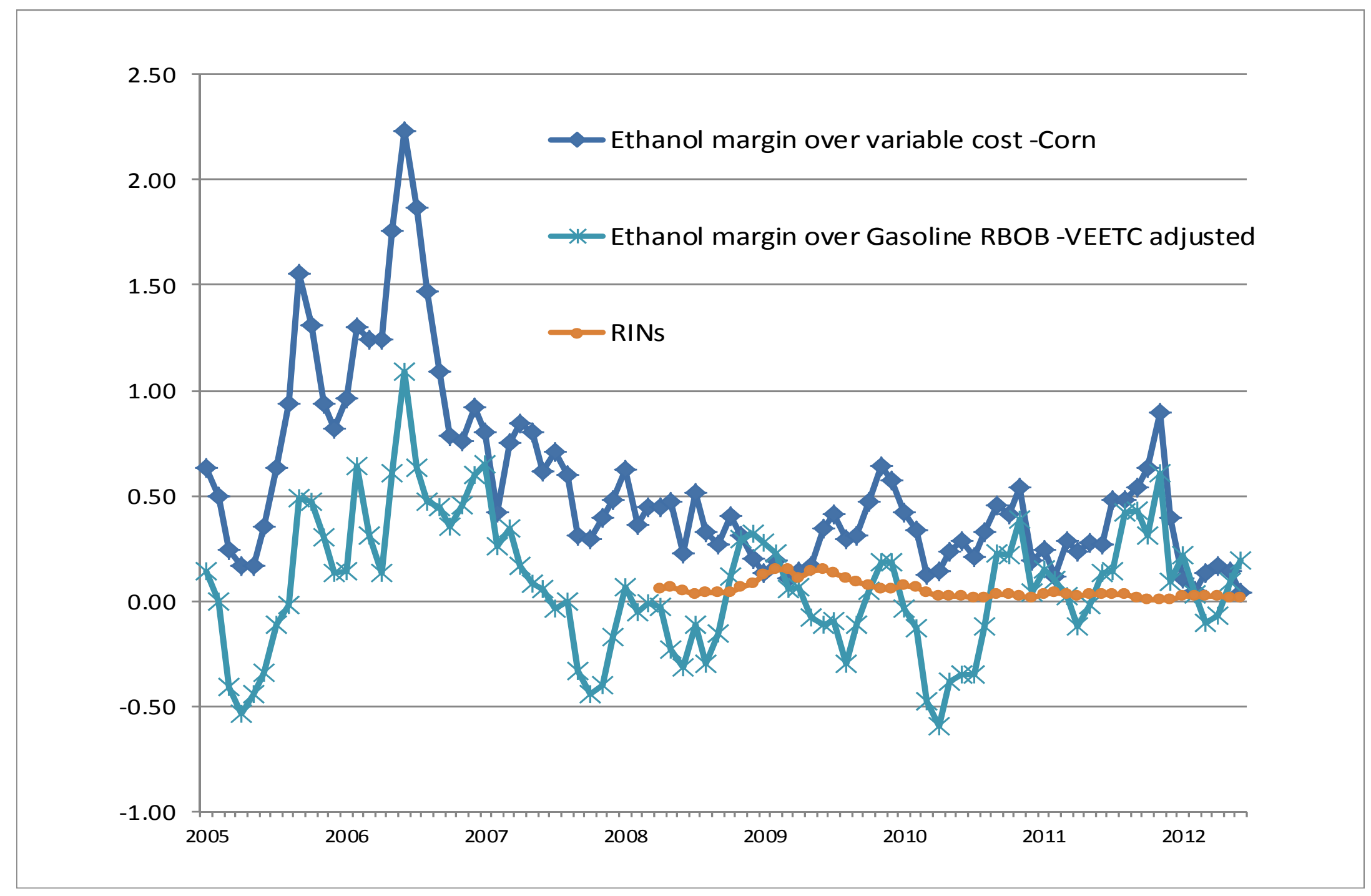

Sources: EIA, 2012; Hofstrand, 2012; OPIS, 2012 
Table 1. Crude Oil and Corn Price Volatility, 1960-2012

\begin{tabular}{|c|c|c|c|c|c|c|}
\hline & & $1960-2012$ & $1998-2005$ & 2006-2012 & 2007-08 & 2010-12 \\
\hline \multicolumn{7}{|l|}{ Means } \\
\hline Crude Oil & $\$ /$ barrel & 24.27 & 28.57 & 81.59 & 84.08 & 94.89 \\
\hline Corn & $\$ / m t$ & 106.52 & 98.06 & 197.32 & 193.25 & 245.17 \\
\hline \multicolumn{7}{|c|}{ Standard deviations } \\
\hline \multirow[t]{3}{*}{ Crude oil } & Annual & 26.24 & 13.21 & 18.59 & --- & --- \\
\hline & Monthly & 25.58 & 12.26 & 21.97 & 25.35 & 14.81 \\
\hline & Daily & --- & 13.04 & 20.44 & 26.03 & 10.97 \\
\hline \multirow[t]{3}{*}{ Corn } & Annual & 51.24 & 8.30 & 62.46 & --- & --- \\
\hline & Monthly & 49.46 & 11.15 & 61.25 & 41.55 & 57.13 \\
\hline & Daily & --- & 10.63 & 59.13 & 42.89 & 54.66 \\
\hline \multicolumn{7}{|c|}{ Coefficients of variation } \\
\hline \multirow[t]{3}{*}{ Crude oil } & Annual & 1.08 & 0.46 & 0.23 & --- & --- \\
\hline & Monthly & 1.05 & 0.43 & 0.27 & 0.30 & 0.16 \\
\hline & Daily & & 0.46 & 0.25 & 0.31 & 0.12 \\
\hline \multirow[t]{3}{*}{ Corn } & Annual & 0.48 & 0.08 & 0.32 & --- & --- \\
\hline & Monthly & 0.46 & 0.11 & 0.31 & 0.22 & 0.23 \\
\hline & Daily & --- & 0.11 & 0.30 & 0.22 & 0.22 \\
\hline \multicolumn{7}{|l|}{ Correlations } \\
\hline \multirow[t]{3}{*}{ Crude oil-Corn } & Annual & 0.88 & 0.30 & 0.87 & --- & --- \\
\hline & Monthly & 0.85 & 0.13 & 0.81 & 0.89 & 0.89 \\
\hline & Daily & --- & -0.06 & 0.71 & 0.86 & 0.77 \\
\hline
\end{tabular}

Sources: Annual and Monthly prices are "world prices" (cash, fob) from IMF Commodity Price Statistics. Daily prices are nearby futures prices from DATASTREAM (Thompson Reuters, 2012). 
Table 2. Watershed Periods for Ethanol Related Constraints.

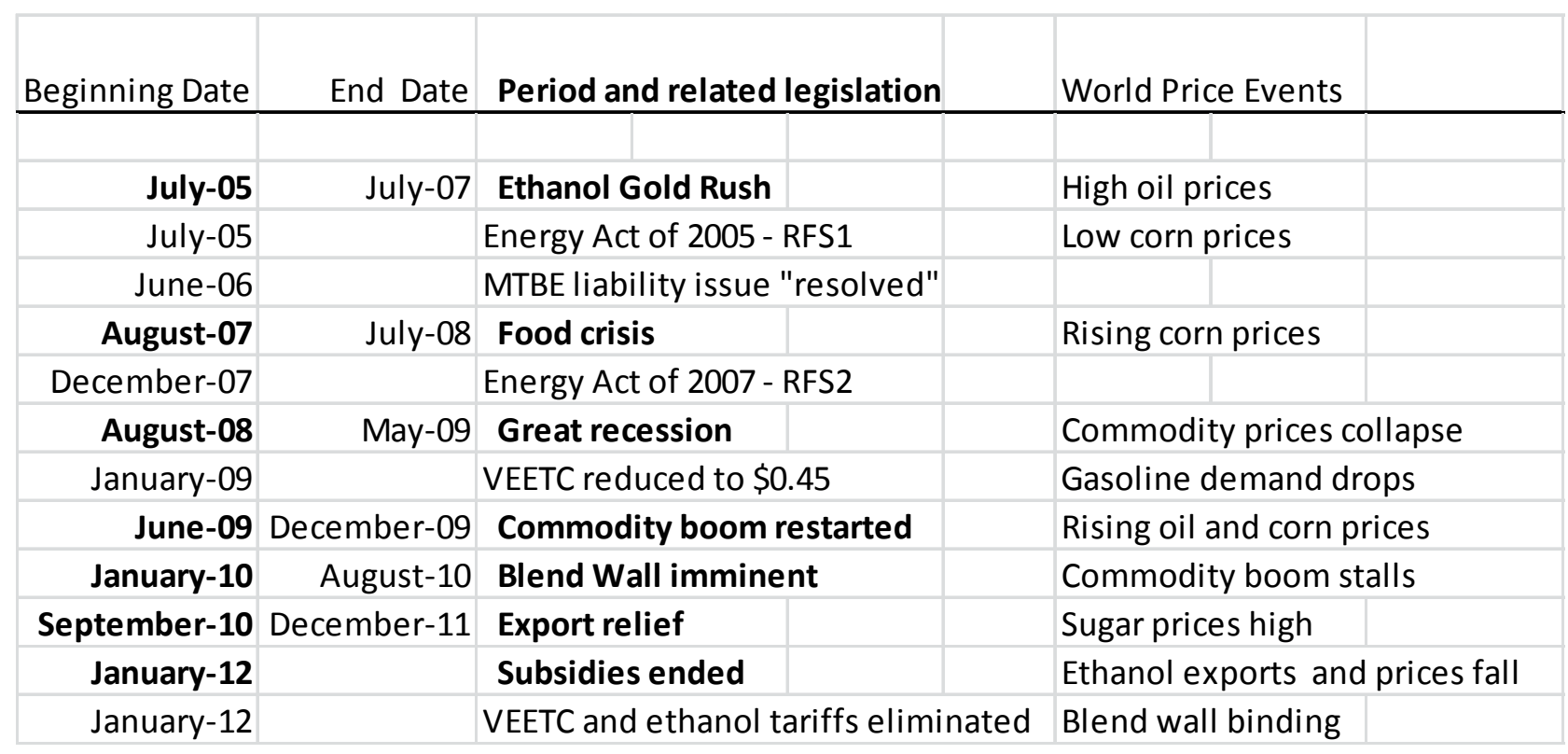


Table 3. Energy and Corn Prices by Watershed Period.

\begin{tabular}{|l|r|r|r|r|r|}
\hline & Crude oil & $\begin{array}{r}\text { Gasoline } \\
\text { RBOB }\end{array}$ & Ethanol & $\begin{array}{r}\text { Gasoline } \\
\text { retail }\end{array}$ & Corn \\
\hline & 1.77 & 2.15 & 2.00 & 2.90 & 3.93 \\
\hline $2005-2012$ & 1.07 & 1.45 & 1.23 & 2.12 & 1.82 \\
\hline Early 2005 & 1.39 & 1.88 & 2.16 & 2.64 & 2.43 \\
\hline Ethanol Gold Rush & 2.23 & 2.56 & 2.10 & 3.29 & 4.48 \\
\hline Food Crisis & 1.45 & 1.64 & 1.70 & 2.52 & 3.95 \\
\hline Great recession & 1.63 & 1.90 & 1.72 & 2.63 & 3.53 \\
\hline Commodity boom & 1.79 & 2.11 & 1.59 & 2.81 & 3.46 \\
\hline Blend wall imminent & 2.29 & 2.65 & 2.45 & 3.40 & 6.22 \\
\hline Export relief & 2.57 & 3.00 & 2.11 & 3.75 & 6.29 \\
\hline Subsidies ended & & & & & \\
\hline
\end{tabular}

Table 4. Ethanol Margins by Watershed Period.

\begin{tabular}{|l|r|r|r|r|r|}
\hline & $\begin{array}{r}\text { Production } \\
\text { margin over } \\
\text { variable cost }\end{array}$ & $\begin{array}{r}\text { Margin over } \\
\text { Gasoline RBOB, } \\
\text { VEETC adjusted }\end{array}$ & RINs & $\begin{array}{r}\text { Import } \\
\text { margin }\end{array}$ & $\begin{array}{r}\text { Export } \\
\text { margin }\end{array}$ \\
\hline 2005 -2012 & 0.54 & 0.07 & & 0.43 & 0.34 \\
\hline Early 2005 & 0.34 & -0.27 & & 0.36 & 0.59 \\
\hline Ethanol Gold Rush & 1.08 & 0.36 & & 0.24 & 0.01 \\
\hline Food Crisis & 0.45 & -0.16 & 0.05 & 0.27 & 0.33 \\
\hline Great recession & 0.23 & 0.10 & 0.09 & 0.04 & 0.72 \\
\hline Commodity boom & 0.40 & -0.03 & 0.10 & -0.12 & 0.51 \\
\hline Blend wall imminent & 0.26 & -0.31 & 0.03 & 0.96 & 0.61 \\
\hline Export relief & 0.40 & 0.20 & 0.02 & 0.93 & 0.22 \\
\hline Subsidies ended & 0.11 & 0.06 & 0.02 & 1.16 & 0.64 \\
\hline
\end{tabular}

Sources: EIA, 2012; Hofstrand, 2012; OPIS, 2012; ITC, 2012 and author calculations. 
Table 5. Price Volatility by Watershed Period

\begin{tabular}{|l|r|r|r|r|r|}
\hline & Crude oil & $\begin{array}{r}\text { Gasoline } \\
\text { RBOB }\end{array}$ & Ethanol & $\begin{array}{r}\text { Gasoline } \\
\text { retail }\end{array}$ & Corn \\
\hline 1960-2012 & 1.05 & & & & 0.46 \\
\hline $2005-2012$ & 0.31 & 0.27 & 0.22 & 0.20 & 0.43 \\
\hline Early 2005 & 0.09 & 0.10 & 0.15 & 0.08 & 0.03 \\
\hline Ethanol Gold Rush & 0.09 & 0.16 & 0.16 & 0.12 & 0.34 \\
\hline Food Crisis & 0.22 & 0.19 & 0.18 & 0.14 & 0.27 \\
\hline Great recession & 0.47 & 0.42 & 0.18 & 0.33 & 0.17 \\
\hline Commodity boom & 0.09 & 0.06 & 0.10 & 0.05 & 0.09 \\
\hline Blend wall imminent & 0.04 & 0.06 & 0.08 & 0.02 & 0.04 \\
\hline Export relief & 0.12 & 0.14 & 0.11 & 0.11 & 0.14 \\
\hline mid 2009-2012 & 0.19 & 0.20 & 0.21 & 0.15 & 0.30 \\
\hline
\end{tabular}

Table 6. Price Correlations by Watershed Period.

\begin{tabular}{|l|r|r|r|r|r|}
\hline & $\begin{array}{r}\text { rrude oil/ } \\
\text { Corn }\end{array}$ & $\begin{array}{r}\text { Ethanol/ } \\
\text { Corn }\end{array}$ & $\begin{array}{r}\text { Ethanol/ } \\
\text { Gasoline }\end{array}$ & $\begin{array}{r}\text { Crude oil/ } \\
\text { Gasoline }\end{array}$ \\
& 0.85 & & & & \\
Corn & & & & \\
\hline $1960-2012$ & 0.83 & 0.52 & 0.67 & 0.95 & 0.70 \\
\hline $2005-2012$ & -0.13 & -0.08 & 0.62 & 0.90 & 0.70 \\
\hline Ethanol Gold Rush & 0.94 & 0.92 & 0.89 & 0.99 & 0.71 \\
\hline Food Crisis & 0.96 & 0.95 & 0.96 & 0.98 & -0.29 \\
\hline Great recession & -0.12 & 0.39 & 0.52 & 0.73 & 0.81 \\
\hline Commodity boom & 0.04 & 0.71 & -0.69 & 0.78 & 0.94 \\
\hline Blend wall imminent & 0.83 & 0.77 & 0.73 & 0.90 & 0.85 \\
\hline Export relief & & & & \\
\hline
\end{tabular}

Sources: Author calculations from EIA, 2012; Hofstrand, 2012 


\section{References}

ABBOTT, P. 2010. Stabilization Policies in Developing Countries after the 2007-08 Food Crisis. OECD Working Paper TAD/CA/APM/WP(2010)44. Paris: OECD.

ABBOTT, P., HURT, C. \& TYNER, W. 2008. What's Driving Food Prices? : Farm Foundation Issue Report.

ABBOTT, P. C., HURT, C. \& TYNER, W. E. 2011. What's Driving Food Prices in 2011 ? Oak Brook, IL: Farm Foundation.

AGRICULTURAL FOOD AND POLICY CENTER 2008. The Effects of Ethanol on Texas Food and Feed. College Station, TX: Texas A\&M University.

AI, C., CHATRATH, A. \& SONG, F. 2006. On the Co-movement of Commodity Prices. American Journal of Agricultural Economics, 88, 574-588.

BABCOCK, B. A. \& FABIOSA, J. F. 2011. The Impact of Ethanol and Ethanol Subsidies on Corn Prices: Revisiting History. Ames, Iowa: Center for Agricultural and Rural Development (CARD).

BAFFES, J. \& HANIOTIS, T. 2010. Placing the 2006/08 Commodity Price Boom into Perspective Washington DC: World Bank.

BALCOMBE, K. 2009. The Nature and Determinants of Volatility in Agricultural Prices: An Empirical Study from 1962-2008 Workshop on Institutions and Policies to Manage Global Market Risks and Price Spikes in Basic Food Commodities. Rome: FAO.

BROWN, L. R. 1980. Food or fuel: new competition for the world's cropland, Washington, DC, Worldwatch Institute.

CARTER, C., RAUSSER, G. \& SMITH, A. 2012. The Effect of the U.S. Ethanol Mandate on Corn Prices. Giannini Foundation Working Paper. Davis, CA: Univ. of California.

CHA, K. S. \& BAE, J. H. 2011. Dynamic impacts of high oil prices on the bioethanol and feedstock markets. Energy Policy, 39, 753-760.

COLLINS, K. 2008. The Role of Biofuels and Other Factors in Increasing Farm and Food Prices. Chicago: Kraft Global Foods.

COOPER, G. 2011. The Ethanol Shuffle. The E-Exchange. Washington DC: Renewable Fuels Association.

CUI, J., LAPAN, H., MOSCHINI, G. \& COOPER, J. 2011. Welfare Impacts of Alternative Biofuel and Energy Policies. American J. of Agricultural Economics, 93, 1235-1256.

DEGORTER, H. D. \& JUST, D. R. 2009. The Economics of a Blend Mandate for Biofuels Am. J. Agr. Econ., 91, 738-50.

DELGADO, C. Year. Driven by Increased Price Volatility, the Global Food Crisis is Not Over. In: Policy Dialogue on High Food Prices: Outlook and Donor Mid-term Responses, February 12-13, 20092009 Paris. OECD.

DIFFENBAUGH, N. S., HERTEL, T. W., SCHERER, M. \& VERMA, M. 2012. Response of corn markets to climate volatility under alternative energy futures. Nature Climate Change, advance online publication. 
DU, X. \& HAYES, D. J. 2009. The impact of ethanol production on US and regional gasoline markets. Energy Policy, 37, 3227-3234.

EIA 2000. MTBE, Oxygenates, and Motor Gasoline. Washington DC: Energy Information Administration, Department of Energy

EIA 2012. Monthly Energy Review. Washington DC: Energy Information Administration, Dept. of Energy.

ELOBEID, A., TOKGOZ, S., HAYES, D. J., BABCOCK, B. A. \& HART, C. E. 2007. The Long-Run Impact of Corn-Based Ethanol on the Grain, Oilseed, and Livestock Sectors with Implications for Biotech Crops. AgBioForum, 10, 11-18.

ELOBEID, A. \& TOKGOZ, S. 2008. Removing Distortions in the U.S. Ethanol Market: What Does It Imply for the United States and Brazil? American Journal of Agricultural Economics, 90, 918-932.

ENDERS, W. \& HOLT, M. T. 2012. Sharp Breaks or Smooth Shifts? an Investigation of the Evolution of Primary Commodity Prices. American Journal of Agricultural Economics, 94, 659-673.

ERS 2012. Feed grain database. USDA, Washington DC..

FOOD AND AGRICULTURAL POLICY RESEARCH INSTITUTE (FAPRI) 2011. US

Biofuels Baseline and impact of extending the $\$ 0.45$ ethanol blenders credit. Columbia, MO: Food and Agricultural Policy Research Institute (FAPRI) at the University of Missouri-Columbia.

GILBERT, C. L. 2010. How to understand high food prices. Journal of Agricultural Economics, 61, 398-425.

GOHIN, A. \& TRÉGUER, D. 2010. On the (De) Stabilization Effects of Biofuels: Relative Contributions of Policy Instruments and Market Forces. Journal of Agricultural and Resource Economics, 35, 72-86.

HARRI, A., NALLEY, L. \& HUDSON, D. 2009. The Relationship between Oil, Exchange Rates, and Commodity Prices. Journal of Agricultural and Applied Economics, 41, 501510.

HEADEY, D. \& FAN, S. 2010. Reflections on the Global Food Crisis, Washington, DC, IFPRI. HERTEL, T., TYNER, W. \& BIRUR, D. 2010. The Global Impacts of Multinational Biofuels Mandates. Energy Journal, 31(1), 75-100.

HERTEL, T. W. \& BECKMAN, J. 2012. Commodity Price Volatility in the Biofuel Era: An Examination of the Linkage between Energy and Agricultural Markets. Cambridge, MA: NBER.

HOCHMAN, G., RAJAGOPAL, D. \& ZILBERMAN, D. 2011. The Effect of Biofuels on the International Oil Market. Applied Economic Perspectives and Policy, 33, 402-427.

HOFSTRAND, D. 2012. Ethanol Supply Chain Profitability. Ames, Iowa: Agricultural Marketing Resource Center, Iowa State University.

INTERNATIONAL MONETARY FUND (IMF) 2008. Food and Fuel Prices-Recent Developments, Macroeconomic Impact, and Policy Responses: An Update. Washington, DC: International Monetary Fund. 
INTERNATIONAL MONETARY FUND (IMF). 2012. International Commodity Prices

[Online]. Washington DC: International Monetary Fund. Available:

http://www.imfstatistics.org/imf/ [Accessed April 2012].

IRWIN, S. H. \& SANDERS, D. R. 2011. Index Funds, Financialization, and Commodity Futures Markets. Applied Economic Perspectives and Policy, 33, 1-31.

ITC 2012. Trade dataweb. Washington DC: International Trade Commission, Dept. of Commerce.

JUST, D. R. \& JUST, R. E. 2008. Monopoly Power, Futures Market Manipulation, and the Oil Price Bubble. Journal of Agricultural \& Food Industrial Organization, 6, Article 2.

KESAM, J. P., OHYAMA, A. \& YANG, H. S. 2011. An Economic Evaluation of the Renewable Fuel Standard (RFS) Biofuel Program: An Industrial Policy Approach. UrbanaChampaign, IL: University of Illinois.

KHANNA, M., ANDO, A. W. \& TAHERIPOUR, F. 2008. Welfare Effects and Unintended Consequences of Ethanol Subsidies. Applied Economic Perspectives and Policy, 30, 411 421.

MCPHAIL, L., WESTCOTT, P. \& LUTMAN, H. 2011. The Renewable Identification Number System and U.S. Biofuel Mandates. Washington DC: Economic Research Service, United States Department of Agriculture.

MCPHAIL, L. L. 2011. Assessing the impact of US ethanol on fossil fuel markets: A structural VAR approach. Energy Economics, 33, 1177-1185.

MCPHAIL, L. L. \& BABCOCK, B. A. 2012. Impact of US biofuel policy on US corn and gasoline price variability. Energy, 37, 505-513.

MITCHELL, D. 2008. A note on rising food prices. Washington, DC: World Bank.

NATIONAL ACADEMY OF SCIENCES 2011. Renewable Fuel Standard: Potential Economic and Environmental Effects of U.S. Biofuel Policy (2011) Washington DC: National Academies Press.

NEWMAN, D. 2011. U.S. Ethanol Policy and Trade. Washington DC: U.S. International Trade Commission.

OECD 2008. Biofuel Support Policies: An Economic Assessment. Organization for Economic Cooperation and Development, Paris.

OPIS 2012. Ethanol RINs. Gaithersburg, MD: Oil Price Information Service.

PAULSON, N. 2012. Is the Ethanol Mandate Truly a Mandate? An Estimate of Banked RINs

Stocks. Farmdoc Daily. Illinois FBFM and Department of Agricultural and Consumer

Economics, University of Illinois

RAJAGOPAL, D., SEXTON, S. E., ROLAND-HOLST, D. \& ZILBERMAN, D. 2007.

Challenge of biofuel: filling the tank without emptying the stomach? Environmental Research Letters, 2, 044004.

RFA 2010. The Paradox of Rising U.S. Ethanol Exports: Increased Market Opportunities and the Expense of Enhanced national Security? Washington DC: Renewable Fuels Association. RFA 2012. Ethanol Industry Statistics. Washington DC: Renewable Fuels Association. 
SEARCHINGER, T. 2008. Summaries of Analyses in 2008 of Biofuels Policies by International and European Technical Agencies. Washington, DC: The German Marshall Fund of the United States.

THOMPSON, W., MEYER, S. \& WESTHOFF, P. 2010. The New Markets for Renewable Identification Numbers. Applied Economic Perspectives and Policy, 32, 588-603.

THOMSON REUTERS 2012. Datastream. Thomson Reuters.

TIMILSINA, G. R. \& SHRESTHA, A. 2010. Biofuels: Markets, Targets and Impacts. Washington DC: World Bank.

TROSTLE, R. 2009. Fluctuating Food Commodity Prices: A Complex Issue With No Easy Answers. Amber Waves, 6, 11-17.

TYNER, W. \& VITERI, D. 2010. Implications of blending limits on the US ethanol and biofuels markets. Biofuels, 1, 251-253.

TYNER, W. E. 2008. The US Ethanol and Biofuels Boom: Its Origins, Current Status, and Future Prospects. BioScience, 58, 646-53.

TYNER, W. E. 2010. The integration of energy and agricultural markets. Agricultural Economics, 41, 193-201.

TYNER, W. E. \& TAHERIPOUR, F. 2008. Policy Options for Integrated Energy and Agricultural Markets. Applied Economic Perspectives and Policy, 30, 387-396.

TYNER, W. E., TAHERIPOUR, F. \& PERKIS, D. 2010. Comparison of fixed versus variable biofuels incentives. Energy Policy, 38, 5530-5540.

U.S. CONGRESS 2005. Energy Policy Act of 2005, Public Law 109-58. Washington, D.C.

U.S. CONGRESS 2007. Energy Independence and Security Act of 2007. H.R. 6, 110 Congress, 1st session.

VALDES, C. 2011. Brazil's Ethanol Industry: Looking Forward. Washington DC: Economic Research Service, United States Department of Agriculture.

WILliAMS, J. C. \& WRIGHT, B. D. 1991. Storage and Commodity Markets, Cambridge, Cambridge University Press.

WISNER, R. 2012. Ethanol Exports: A Way to Scale the Blend Wall? Renewable Energy \& Climate Change Newsletter. Ames, Iowa: Agricultural Marketing Resource Center.

WRIGHT, B. 2001. Storage and Price Stabilization. In: RAUSSER, B. G. A. G. (ed.) Handbook of Agricultural Economics. Baltimore, MD: Hopkins University.

WRIGHT, B. D. 2009. Speculators, Storage, and the Price of Rice. Giannini Foundation of Agricultural Economics. Berkeley, CA: Giannini Foundation of Agricultural Economics, University of California, Berkeley.

WRIGHT, B. D. 2011. The Economics of Grain Price Volatility. Applied Economic Perspectives and Policy, 33, pp. 32-58. 


\section{Endnotes}

${ }^{1}$ The Renewable Fuels Association (RFA, 2012) and others (e.g. Abbott, Hurt and Tyner, 2011) assert the net demand for corn is closer to $28 \%$, as distiller's dry grain, a by-product of ethanol production, provides feed to replace about one-third of the corn used for ethanol.

${ }^{2}$ For these series, differing means over time are due to more than inflation. Coefficients of variation calculated for monthly data on prices deflated by the U.S. CPI from 1960 to 2012 are lower for crude oil, falling from 1.05 to 0.68 , but are nearly identical for corn, at 0.45 . It is evident from Figure 1 that real prices have varied significantly over this long time period.

${ }^{3}$ Some use variances, which are essentially standard deviations squared. The standard deviation is preferred here because it is in units of measure comparable to the mean price, and squaring this measure would distort the perception of the extent of variability. Coefficients of variation divide standard deviations by corresponding means, to normalize the measure of variability, to facilitate comparisons across series with differing means, and to correct for the fact that as a nominal price increases, its standard deviation is likely to increase in the same proportion - and that does not correspond with the notion of increased volatility.

${ }^{4}$ Regime changes correspond with changes in the mechanisms that are most important in determining market prices - which could be policies or real external shocks. For example, a binding RFS mandate and a binding "blend wall" are different regimes. Similarly, periods of low corn stocks (food crisis) and of abundant corn stocks (ethanol gold rush) give rise to different regimes.

${ }^{5}$ Blenders are allowed to decide whether RINs acquired in a given year are applied in that year or an adjacent year, so the mandate does not strictly limit production in a given calendar year. That mechanism allows RINs to be traded across years as well as across firms. Paulson (2012) argues that this has contributed to very low observed values for RINs for corn ethanol.

${ }^{6}$ The EPA no longer uses a specific oxygenate requirement, but continues to regulate carbon monoxide emissions. Both MTBE and ethanol are used to reduce those emissions in gasoline blending.

${ }^{7}$ From this point forward we will work at the market level. Issues related to heterogeneous firms will be left for future research.

${ }^{8}$ Net export supply from the U.S. in the right panel of Figure 3 represents the difference between supply and overall demand in the left panel. Overall demand is the sum of the separate domestic demand components - feed, food, seed and industrial uses. Equilibrium equates net export supply by the U.S. with net foreign demand for corn.

${ }^{9}$ Unit values, equal to the value of imports or exports divided by the corresponding quantity of imports or exports, are a commonly used but imperfect proxy for border prices. If ethanol is a relatively homogeneous product then these should be a reasonable approximation, but there is some diversity in the quality of products traded. 
${ }^{10}$ The EIA now reports both "nameplate" and "sustainable" capacity. "Sustainable" capacity is about $4 \%$ higher. Nameplate capacity used here is as reported by RFA.

${ }^{11}$ Monthly price series include too few observations to determine volatility and correlations after ethanol subsidies ended in 2012. 